WIDER Working Paper 2017/23

\title{
Modeling sustainable long-term electricity supply-demand in Africa
}

Nadia S. Ouedraogo*

February 2017 
Abstract: This paper develops a scenario-based model to identify and provide an array of electricity demand in Africa, and to derive them from the African power system of development. A system-based approach is performed by applying the scenario methodology developed by Schwartz in the context of the energy-economic modeling platform 'Long-range Energy Alternative Planning'. Four scenarios are investigated. The Business as Usual scenario replicates the regional and national master plans. The renewable promotion scenario increases the share of renewable energy in the electricity mix. The demand- and supply-side efficiency scenarios investigate the impact of energy efficiency measures on the power system. The results show an increase in electricity demand by 4 per cent by 2040, supply shortages, and high emissions of greenhouse gases. Contrary to expectations, the renewable energy scenario did not emerge as the best solution to a sustainable electrification of the region. The energy efficiency scenarios have allowed us to draw a sustainable pathway for electrification.

Keywords: energy planning model simulation, electricity, sustainable development, climate change, Africa

*United Nations Economic Commission for Africa (UNECA), Addis Ababa, Ethiopia; NOuedraogo@uneca.org.

This study has been prepared within the UNU-WIDER project on 'Africa's energy futures'.

Copyright (C) UNU-WIDER 2017

Information and requests: publications@wider.unu.edu

ISSN 1798-7237 ISBN 978-92-9256-247-2

Typescript prepared by Lesley Ellen.

The United Nations University World Institute for Development Economics Research provides economic analysis and policy advice with the aim of promoting sustainable and equitable development. The Institute began operations in 1985 in Helsinki, Finland, as the first research and training centre of the United Nations University. Today it is a unique blend of think tank, research institute, and UN agency_providing a range of services from policy advice to governments as well as freely available original research.

UNU-WIDER acknowledges specific programme contribution from the National Treasury of South Africa to its project 'Regional growth and development in Southern Africa' and core financial support to its work programme from the governments of Denmark, Finland, Sweden, and the United Kingdom.

Katajanokanlaituri 6 B, 00160 Helsinki, Finland

The views expressed in this paper are those of the author(s), and do not necessarily reflect the views of the Institute or the United Nations University, nor the programme/project donors. 
Despite Africa's large energy endowment and the progress achieved in the establishment of regional power pools over the last two decades, the power network in Africa is still underdeveloped with inadequate generation systems, leaving millions of people in Africa without electricity.

Nearly two-thirds of Africans (more than 620 million people) do not have access to electricity (IEA 2014b). And the per capita electricity consumption is very low in the majority of sub-Saharan Africa (SSA) countries, reaching on average only $17 \mathrm{~kW}$-hours ( $\mathrm{kW}$ h) per year $(225 \mathrm{~kW}$ h if South Africa is excluded). Moreover, those that do have access are facing high prices for an unreliable supply with frequent power outages. Scheduled blackouts, as well as random power outages, are a daily occurrence in the region. The economic losses due to the power interruptions are estimated to vary annually from 1 per cent to 5 per cent of the gross domestic products (GDP) of the countries (IRENA 2015a, 2015b). This energy poverty (i.e. a lack of access to modern energy services or access to unreliable energy sources) is believed to hinder economic growth in African economies (Ouedraogo 2012, 2013).

This situation is expected to get worse as population, urbanization, and income are projected to rise, driving up electricity demand that is predicted to increase significantly in the coming years. This will put a future strain on the currently insufficient generating capacity and poor regional and national power infrastructure.

Therefore, there is an urgent need to raise and improve the capacity of the power sector in Africa. Power systems planning, which consists of ensuring that energy-related policy and investment decisions consider all possible power supply- and demand-side options, is critical. That will help improve power generation, anticipate, and respond to the increase in energy demand for sustainable development in Africa.

A prerequisite to power systems planning is an electricity demand forecast, which is the prediction of demand for power in the future. Forecasting is an important component of power system management. Precise forecasting helps the electric power companies make unit commitment decisions, reduce the spinning reserve capacity, and properly schedule device maintenance plans (Amina and Kodogiannis 2011). It also reduces the generation cost and increases the reliability of the power system.

Rigorous demand forecasting is crucial in developing countries with low rates of electrification in order to support effective development of the power systems. Sound predictions of demands and demand trends in a highly uncertain environment are more than ever needed to convince outside investors (e.g. private sector, bi- and multi-lateral investors, project shareholders, etc.) (SNC Lavalin International Inc. and Parsons Brinkerhoff 2011). Long-term planning is necessary to support optimal allocations of the investments in developing countries.

Nevertheless, there are currently several obstacles to producing such studies for developing countries, including SSA countries. Besides data paucity and quality, particularly regarding renewable resources data, and a shortage of expertise (IRENA 2015a, 2015b; Bazilian et al. 2012), the analysis methods and the tools used are not always appropriated to the respective regions, including their policies, and investment questions.

Indeed, energy forecasting models in developing countries are derived from those of industrialized countries. Consequently, it is assumed that the energy systems of developing regions will behave 
like those of developed regions and that they will follow the historic development trajectories of developed countries (Shukla 1995). However, the developing countries have their own characteristics which differ from those of developed countries and extrapolating the energy modeling technique of these later to low-income countries may result in biased models and inadequate modeling of the energy systems of developing countries (Urban et al. 2007).

Overall, the existing modeling frameworks give a partial view of the energy systems in Africa and the related issues they are facing, and result in fragmented results and figures, making their understating as complementary pieces of information by policy makers difficult (Bazilian et al. 2012).

For better planning objectives, there is, thus, a need for developing new or improved existing energy models which will adequately address the characteristics of African countries' energy systems and economies.

This study develops a scenario-based model to quantitatively analyse the current status of power generation and predict the composition of the future generation profile, and the associated global warming potential. The energy-economic modeling platform Long-range Energy Alternative Planning (LEAP), which emerged as the most suitable energy modeling framework for developing countries, is applied to analyse the regional power systems expansion and explore different potential scenarios to achieve universal access to electricity, as well as their associated greenhouse gas (GHG) emissions. These scenarios include the deployment of renewable energies and demandand supply-side energy efficiency policies. Contrary to the existing literature, a detailed representation of the African power system is proposed. All the end-users and supply-side activities and actors are considered.

To the best of our knowledge, this study is one of the first detailed and complete models of the African regional electricity systems.

The remainder of the paper is as follows: Section 2 presents the literature review on the long-term electricity forecasting. The power sector of Africa is described in Section 3. The empirical methodology and the sources of data are described in Section 4. The results are discussed in Section 5 and, Section 6 concludes the discussion.

\section{Literature review}

The need for accurate and efficient power system planning, as well as for handling the increasing complexity and number of parameters that influence the trends of electricity demand (Santos et al. 2007) has led to the evolution and development of forecasting methods over the last few decades. Today, a diverse array of energy models employing a variety of different techniques, which have been used to analyse a wide range of issues, exists. ${ }^{1}$

\footnotetext{
${ }^{1}$ It should be noted that, if model, tool, and modeling framework are used interchangeably throughout the literature, these are, in a strict sense, different. An energy model is a simplified representation of a specific energy system, and a tool or modeling framework model refers to the computer programme used to create the different models (Timmerman et al. 2014).
} 
Table 1 displays the main long-term global energy models existing today. Tables A1 and A2 in the Appendix display a description and a classification of energy systems models as well as their options, purpose, and structure ${ }^{2}$ (see Table A3).

Primarily built and used in the developed countries, some of these models, however, have been applied to assess the energy systems in developing countries, including SSA countries. Nevertheless, energy systems of the developing world present different characteristics from those of the industrialized world that, many forecasting models biased towards the latter, fail to adequately address (Urban et al. 2007). These characteristics include the informal economy, supply shortages, poor performance of the power sector, structural economic change, low electrification rate, high share of traditional biomass, and rural households.

By analysing the number of main characteristics of developing countries addressed per model Urban et al. (2007) showed that, among the above cited-methods, LEAP, MESSAGE, (Model for Energy Supply Strategy Alternatives and their General Environmental impact) and the WEM (World Energy Model) are those which address a large number of developing countries' characteristics. ${ }^{3}$

Among these three models, LEAP has been selected as the preferred framework to elaborate upon scenarios regarding the development of the African power system for different reasons.

First for all, while the WEM of the International Energy Agency (IEA) is a simulation model covering energy demand, energy transformation, and energy supply, including the majority of the end-use sectors and energy-related $\mathrm{CO}_{2}$ emissions, the model is a 'black box' that is not available for public use.

Secondly, MESSAGE is an optimization model used to optimize energy investment decisions by finding the best solutions; that means that investment and operating cost data are of prime importance in this model. However, such data availability, within the context of African countries, is sparse. Moreover, optimization models assume the existence of optimal consumer behaviour and perfect markets; market imperfections and obstacles as in Africa's context are not considered, resulting in improbably low projections of energy demand (Schade et al. 2009; Herbst et al. 2012; Semertzidis 2015).

In contrast to optimization models, such as MESSAGE, that provide an image of what would be an optimal trajectory, the LEAP model is an integrated assessment tool that can be used to represent plausible future trajectories. It allows for the track of energy resource extraction, production, and consumption in all sectors of an economy as well as for the simulation and assessment of the impacts of alternative energy policies on energy systems. It can also be used to track energy sector and non-energy sector GHG and local pollutants emissions (SEI 2006). Therefore, LEAP can be used to compare alternative electricity generation systems over the medium to long term in order to enable economic and environmental impact analysis (Mcpherson and Karney 2014).

\footnotetext{
${ }^{2}$ For complete reviews of the energy system models, tools and modeling frameworks refer to Urban et al. (2007) and Bhattacharyya and Timilsina (2010).

${ }^{3}$ The RETScreen has also been identified by Urban et al. (2007), as one of the models addressing a large number of developing countries' characteristics. However, RETScreen is a local, technology-specific tool, used to assess and optimise the technical feasibility and financial viability of potential clean energy projects (Government of Canada n.d.).
} 
The LEAP model is more specifically suitable to the modeling of energy systems with sparse historical macro-economic data for trend analysis and/or short-run development issues. Indeed, the initial data requirement of LEAP is very low. Only the base year requires detailed statistical data. Given the lack of quality time series in the African countries' context, the LEAP model is, thus, a good option.

Moreover, LEAP is flexible and transparent and allows for the incorporation of data and results from other models (SEI 2006).

It should also be noted that LEAP is free for use in developing countries with a user-friendly interface and so is well-suited for the purposes of knowledge and skill transferring.

Consequently, the LEAP modeling framework is best-suited to the modeling and forecasting exercise on African countries and an in-depth regional analysis.

LEAP is not new and has already been widely used in the literature to carry out studies in more than 190 countries, applied on the municipal, national, regional, and global scales (Rogan et al. 2014). However, to the best of our knowledge, there is no regional-level electricity system model developed within LEAP for SSA. ${ }^{4}$

Nevertheless, the LEAP model, like the above-mentioned literature, has its fair share of strengths and weaknesses. First of all, the model does not automatically generate optimization or marketequilibrium scenarios. Secondly, economic factors' choices are not considered by the model in determining energy supply and fuel. In addition, shares of fuel usage and substitution among endusers must be determined exogenously and the analysis of fuel competitiveness between renewable energy and fossil fuels cannot be performed. Finally, the model cannot assess the impact of energy policies on the macroeconomic variables (Heaps 2016).

As of the present date, the literature on long-term electricity demand forecasting in SSA consists mainly of aggregate forecasting techniques based on historical trends with exogenous variables, such as future annual grid connections of households. Electricity demand is projected, thanks to some econometric relationships to income and population growth projections associated with the elasticities (Bazilian et al. 2012; Nussbaumer et al. 2012). Nevertheless, such techniques are not adapted to carry out studies on developing countries where a lot of the people lack access to electricity (Bazilian et al. 2012).

Only a few studies which use sophisticated modeling methods to analyse the African power system exist and there are even fewer studies on scenarios modeling the regional power system.

These studies on Africa can be divided into three different groups. The first group of studies uses IMAGE and MESSAGE models, as well as their extensions IMAGEREMG and MESSAGEAccess, and is focused only on individual universal access to electricity, ignoring the other sectors which together account for a large share of total electricity demand in Africa (Riahi et al. 2011; Pachauri et al. 2012; Chakravarty and Tavoni 2013; Pachauri et al. 2013). This forecasting exercise fails to propose alternative policy options to improve electricity availability aside from the target of universal access to electricity which seems unattainable by 2030 (Bazilian et al. 2012). Moreover, this category of studies tends to ignore the supply-side management issues.

\footnotetext{
${ }^{4}$ Sparse studies exist, using LEAP for one country or for sectoral studies in a given country in Africa.
} 
The second group of studies, by using MARKAL and its extensions model (TIMES, GMM MARKAL), consider both the demand and supply sides, but tend to partially analyse the issues related to the energy system in Africa as they do not always consider all the end-users and/or all the supply-side activities and actors. These studies include Howells et al. (2005), Panos et al. (2015) and Panos et al. (2016). Finally, the third group of studies uses the optimization framework, OSeMOSYS, and its extensions models, and is focused on the supply side and interregional trade of energy, capacity expansion planning, and associated finance. These studies consider the demand as exogenous. The main objective of these studies is to determine the cost-optimum supply profile for a specified volume of energy demand, determined exogenously. These studies include Taliotis, Bazilian et al. (2014), Taliotis, Miketa et al. (2014), and Taliotis et al. (2016). They do not consider any demand-side management or energy efficiency measures. However, energy efficiency and demand-side management are crucial in energy management and planning in Africa and should be incorporated into any modeling framework.

Besides this academic literature, there exist several studies conducted by national governmental agencies and regional bodies, international organizations, and consulting companies, using sometimes black-box methods. The Southern African Development Community (SAPP 2009), the Economic Community of West African States (Nexant 2004), East African Community (SNC Lavalin International Inc and Parsons Brinkerhoff 2011), and the Commission de la Communauté Economique et Monétaire de l'Afrique Centrale have conducted forecasting studies on electricity demand. On the regional level, the African Development Bank (AfDB) and the Programme for Infrastructure Development in Africa (PIDA) have also carried out electricity demand forecasting. The IEA also includes Africa in its projection studies in the World Energy Outlook series. Finally, the International Renewable Energy Agency (IRENA) has developed renewable energy deployment scenarios for Africa. Table 2 displays the results of these regional power demand forecast studies.

Overall, the existing research, due to the selection of the modeling techniques and tools, the methodologies and design parameters, and the research and model assumptions of the different studies, fails to provide clear estimates of the distribution of the current and future energy needs and to adequately inform policy makers (Bazilian et al. 2012).

The purpose of this study is to contribute to the body of knowledge and fill some of the gaps that exist in the literature and mentioned above by developing the first regional LEAP model to assess the power system in Africa.

Our contribution to the literature is fourfold. First for all, this study is the first detailed and complete model of the African regional electricity systems, developed within LEAP.

Secondly, in the methodological aspect, this study also contributes to the existing body of knowledge vis-à-vis scenarios for improving electricity access in Africa by analysing plausible scenarios of the regional power system expansion. In addition, demand-side and supply-side energy efficiency measures, crucial in energy management and planning in Africa, are incorporated into the modeling framework. Finally, the GHG and local air pollutant emissions associated with the scenarios of regional power system expansion and increasing demand are assessed.

\section{Overview of Africa's power sector}

Sub-Saharan Africa has the lowest rate of electrification in the world. In 2014, almost 48 per cent of the population lacked access to electricity. Progress on access to modern energy services over 
the past few years has fallen behind population growth (IEA 2014b). Only Cameroon, Côte d'Ivoire, Gabon, Ghana, Namibia, Senegal, and South Africa have a rate of electrification superior to 50 per cent; the remaining countries have an average electrification rate of just 20 per cent (IEA 2014b) (Table 3).

The low rates and disparate level of access to electricity in SSA are due to the poor planning capacity of countries, resulting in inadequate policy and investment decisions in the past (Bazilian et al. 2012). To deal with these issues, the solution, which is based upon the development of their huge available energy potential, in spite of the uneven distribution among the different countries, specifically in the case of hydropower, features a decision made among some African countries to mutualize and share their energy resources and infrastructure with neighbouring countries to reach economies of scale and increase electricity production.

Five power pools corresponding to the five Regional Economic Communities (RECs) exist: (i) the West African Power Pool (WAPP) for the Economic Commission for West African States (ECOWAS); (ii) the Central Africa Power Pool (CAPP) for the Economic Commission for Central African States (ECCAS); (iii) the Eastern Africa Power Pool (EAPP) for the Common Market for Eastern and Southern Africa (COMESA); (iv) the Southern Africa Power Pool (SAPP) for the Southern African Development Community (SADC); and (v) the Comite Maghrébin de l'Electricite (COMELEC) for the Union of Maghreb Arab (UMA) (ICA 2011). A map in the Appendix (Figure A1) shows the boundaries and members of each of the five power pools.

Table 4 gives an overview of the electricity-related situation of each pool. As in 2014, SAPP is the region with the highest installed capacity and CAPP is the region with the lowest installed capacity. The existing electricity capacity is mainly thermal in COMELEC (gas), SAPP (coal), EAPP (gas), and WAPP (gas). The installed capacity is predominantly hydropower in CAPP.

The West African Power Plan (WAPP) covers 14 countries, namely Benin, Burkina Faso, Côte d'Ivoire, Gambia, Ghana, Guinea, Guinea-Bissau, Liberia, Mali, Niger, Nigeria, Senegal, Sierra Leone, and Togo.

The electrification rate in the region is on average 36 per cent. However, this rate hides wide disparities among national electricity access rates and between access in urban and rural areas. The national rates vary from 14 per cent in Niger to 64 per cent in Ghana. The rate of electrification in rural areas is very low, ranging from just 1.2 per cent in Liberia and Sierra Leone to 40 per cent in Ghana. The populations, particularly those in rural areas, are heavily reliant upon traditionally solid fuels, such as dung, wood, and charcoal for their energy needs. Besides that, energy security is also a major issue among the WAPP member states. Energy insecurity in the region includes an unreliable power system, poor infrastructure, and dependence on fuel imports (REN21 2014).

The total installed capacity in WAPP is about $14 \mathrm{GW}$ as of 2014. The region is dependent on gasfired power generation. Hydro is the second large source of power generation. The region still has a vastly untapped hydro potential of approximately $12 \mathrm{GW}$ that includes $3 \mathrm{GW}$ each in Nigeria and Guinea, and 1.6 GW in Ghana (WAPP 2011; REN21 2014). Only two countries (Gambia and Senegal) have real grid-connected wind energy potential. Solar power remains marginal; solar photovoltaics are used only for distributed energy generation and off-grid electrification (REN21 2014).

Ten countries are members of the EAPP: Burundi, Democratic Republic of Congo (DRC), Egypt, Ethiopia, Kenya, Libya, Rwanda, Sudan, Tanzania, and Uganda. 
Around 80 per cent of the population in East Africa lacks access to electricity. The electrification rate varies from 100 per cent for Egypt and 15 per cent for Tanzania to 6 per cent for Burundi. In the other EAPP countries, the shares of population with access to electricity range from 10 to 30 per cent.

The total installed capacity in EAPP is $28 \mathrm{GW}$ with Egypt accounting for more than 70 per cent of this capacity. In EAPP, electricity is largely generated from gas-fired power plants. Hydro power and oil-fired power plants come in the second and third places as generation sources. The region has a largely untapped renewable energy potential. The hydro potential exceeds the current, as well as short- to medium-term, domestic electricity needs. For example, the technical potential of the Grand Inga project in DRC alone is estimated to be over 40 GW (IRENA 2015a, 2015b).

Countries along the Great Rift Valley (Ethiopia, Kenya, the DRC, and Tanzania) have important power potential from geothermal sources (EAPP 2014; IRENA 2015a, 2015b).

The Central African Power Plan (CAPP) covers ten countries: Angola, Burundi, Cameroon, Central African Republic, Chad, DRC, Equatorial Guinea, Gabon, Sao Tomé and Principe, and the Republic of the Congo. Angola and DRC are also members of the SAPP, and some utilities in Burundi and DRC are also members of the EAPP. Electrification rates vary from 66 per cent in Equatorial Guinea and 9 per cent in DR Congo to less than 3 per cent in CAR (IEA 2014b). The installed capacity is $6 \mathrm{GW}$, with an electricity production of $20 \mathrm{TW}$ h. DRC, Angola, and Cameroon account for 80 per cent of the total regional production. Hydropower accounts for about 75 per cent of total installed capacity. The rest of the installed capacity comes from thermal plants (IRENA 2015a, 2015b). The region has important hydro resources which represent 60 per cent of the total hydro energy potential of Africa. Except for Equatorial Guinea, the hydro potential of all countries is significant. Compared to the potential of the other parts of Africa, solar and wind resources are less promising. Chad is the only country with real potential for wind power (IRENA 2015a, 2015b)

The Southern Africa Power Pool (SAPP) includes 12 countries: Angola, Botswana, the DRC, Lesotho, Malawi, Mozambique, Namibia, South Africa, Swaziland, Tanzania, Zambia, and Zimbabwe.

Access to electricity in SAPP ranges from 85 per cent in South Africa to 40 per cent in Zimbabwe and 9 per cent in Malawi (SAPP 2007). For the remaining countries, the rates of electrification range from 40 to 15 per cent.

The total installed capacity in SAPP is $50 \mathrm{GW}$ which generates $320 \mathrm{TW}$ h of electricity. 80 per cent of the total installed capacity is in South Africa. Coal-fired power dominates the regional power mix (SAPP 2007; IRENA 2015a, 2015b).

The region has large renewable resources. Nearly $40 \mathrm{GW}$ of hydropower could be potentially deployed in the short to medium term, with the DRC's Grand Inga accounting for half of the total. Angola, Mozambique, Zambia, and Zimbabwe also have hydro potential of between $1 \mathrm{GW}$ and 7 GW (SAPP 2007; IRENA 2015a, 2015b). All SAPP countries have high solar photovoltaic (PV) and concentrated solar power (CSP) potential and Malawi, South Africa, and Zimbabwe have potential in wind (IRENA 2015a, 2015b). Mozambique, Swaziland, Tanzania, and Zambia have

\footnotetext{
${ }^{5}$ The Eastern DRC system is interconnected with Rwanda and Burundi.
} 
potential in biomass. Bagasse, from their important sugar cane production, could be used for electricity generation (IRENA 2015a, 2015b).

\section{$4 \quad$ Materials and methods}

The Long-range Energy Alternative Planning System (LEAP), developed at the Stockholm Environment Institute of Boston (SEI), is an accounting platform that matches demand with supply-side energy technologies and reports the system impact, including electricity production by type, resource, and global warming potential.

It enables top-down, as well as bottom-up, macroeconomic modeling of the power sector and capacity expansion planning over the medium to long term.

It also incorporates a technology and environment database (TED), a compilation of technical characteristics, costs, and environmental impacts for different energy technologies from sources including the Intergovernmental Panel on Climate Change, the US Department of Energy, and the International Energy Agency (Mcpherson and Karney 2014).

\subsection{Modeling tool}

\subsubsection{Total electricity demand analysis}

Total electricity demand is calculated as a product of total activity and electricity intensity for each sector and year (SEI 2006; Suhono 2015). It is expressed as follows:

$E D_{i s, t}=T A_{i, s, t} x E I_{i s, t}$

In the aforementioned equation, $E D$ is the electricity demand of the sector $i, T A$ is the total activity of the sector $i, E I$ is the electricity intensity, $s$ is the scenario, and $t$ is the time.

Energy intensity at the generator level can be calculated as the quantity of energy consumed per unit of activity. Electricity intensity can therefore be calculated as the product of electricity consumption and total activity.

$$
E I_{i, t}=\frac{E C_{i, t}}{T C_{i, t}} \times E I_{i, t}=\frac{E C_{i, t}}{T C_{i, t}}
$$

where $E I$ is the electricity intensity, $E C$ is the electricity consumed, $T C$ is the total consumers, $i$ is the sector, and $t$ is the time.

From equations (1) and (2), the electricity demand is forecast for each end-user.

For the residential sector, the electricity demand can be forecast by projecting electricity intensity, electrification ratio, population, and household size. For the base year, this demand for the household is calculated as the product of total consumers and electricity intensity. Electricity demand for the following years is obtained by projecting the number of consumers and electricity intensity. The projected number of consumers is calculated as follows. 


$$
T C_{h s, t}=\frac{P_{s, t}}{H S_{s, t}} \chi E R_{s, t}
$$

where $T C_{b}$ is the total consumers in the residential sector, $P$ is population, $H S$ is household size, and $E R$ is the electrification ratio (percentage of households with electricity).

From equation (3), the electricity demand for household is forecast as follows:

$$
E C_{h, s, t}=\frac{P_{s, t}}{H S_{s, t}} \chi E R_{s, t} \chi E I_{h, s, t}
$$

where $E C_{b}$ is electricity consumption and $E I_{b}$ is electricity intensity in the household sector. $P, H S$, $E R, s$, and $t$ are as described above.

Electricity consumption for non-residential sectors is also based on the number of consumers and electricity intensity. The electricity for each non-residential sector is thus forecast by projecting the number of customers and the electricity intensity.

$$
\begin{gathered}
E D_{a s, t}=T C_{a s, t} x E R_{a, s, t} \\
E D_{i s, t}=T C_{i s, t} x E R_{i, s, t} \\
E D_{s y s, t}=T C_{s y, s, t} x E R_{s y s, t}
\end{gathered}
$$

where ED is electricity demand, $a, i$, and $s v$ represent the sectors of agriculture, industry, and services.

Electricity consumption for transformation (electricity consumed at the transmission and distribution modules levels) is calculated for each process as follows:

$$
\text { Input }_{p}=\frac{\text { Output }_{p}}{\text { Efficiency }_{p}}
$$

$$
\text { Efficiency }_{p}=1-\text { Losses }
$$

Input is the fuel or feedstock used in the process of power generation. Output is the amount of electricity generated and Efficiency represents the efficiency of the power plant.

The total domestic electricity demand is then decreased by the outputs and increased by the inputs of the power plants.

\subsubsection{Greenhouse gas emissions}

The total emissions from final energy consumption are calculated as follows:

$$
G H G=\sum_{i} \sum_{j} \sum_{n} A L_{n j, i} \times E I_{n j, i} \times E F_{n j, i}
$$


where $G H G_{T}$ is the emissions resulting from the energy transformation process, ETP is the transformation product, $f$ is the energy transformation efficiency, and $E F_{t, m, s}$ is the emission factor from one unit of primary fuel types used to produce secondary fuel type $t$ through equipment $m$.

\subsection{Basic assumptions and data input}

\subsubsection{Assumptions}

The study develops a regional LEAP model which considers the energy consumption and transformation sectors in the entire region of SSA.

The inputs of the model include gross domestic product, gross domestic product growth, population, and the numbers and sizes of households. Four sectors, (i.e. households, agriculture, industrial, and services) are included in the model. The level of activities (i.e. value added by industry, agriculture, or services) and total annual consumption by each sector are used to determine the final energy intensity required to forecast electricity demand. The energy conversion system includes electricity transmission, distribution, and generation. Electricity generation technologies include oil and gas turbines, combined cycle cogeneration, small and large-scale hydroelectric generators, photovoltaic systems, and wind turbines. In addition, for the different phases of the generation process, information on historical production, exogenous and endogenous capacity, process efficiency, reserve margin, dispatch rule, and lifetime of the plant is provided.

Reserve margin measures the additional generating capacity of a power system to meet peak demand. As such, it is a measurement of an electricity system's ability to continuously meet consumer demand, including periods of unplanned equipment outages and unexpected fluctuations in demand. More specifically, reserve margin is the amount of firm electricity generation capacity minus the system's maximum annual demand as a ratio of maximum annual demand.

The reserve margin constraint is defined as follows:

$$
\sum_{i=1}^{n} \alpha_{i} \times C_{p_{i}} \geqslant(1+R M) D
$$

Where $a^{i}$ is the capacity credit of power plant/technology $i$ or the share of capacity that is considered as 'firm'; $C P_{i}$ is the generating capacity of centralized power plant/technology $i ; R M$ is the reserve margin and $D$ is the peak demand on the centralized grid system.

While it is usually required that producers and transmission facilities maintain a constant fraction of 10-20 per cent of their generating capacity, the current demand-supply ratio in many SSA countries is below 10 per cent. Therefore, an average regional reserve capacity of 10 per cent has been estimated as reasonable in this study.

The system load curve was calculated by taking the hourly demand values. While the maximum demand increased over time, the system load curve is assumed to remain constant over time. This is one of the main limitations of the analysis related to the module. Despite the daily granularity of the data input, LEAP only calculates the total annual generation for each plant (Mcpherson and Karney 2014). 
The system load and the associated peak requirement are shown in the Appendix (Figures A3-A4) However, given that electricity demand differs among countries, in reality, load profiles are country-specific. As an illustration, load-shape figures for one country belonging to each pool are given in the Appendix (Figures A5-A8).

Capacity credit is defined as the share of the rated capacity of a power plant that can be considered firm. For dispatchable power technologies (thermal and large hydropower using dams), the capacity credit is equal to 100 per cent. For variable renewable energy (wind, solar), the capacity credit depends on their share of the total generating capacity and the quality of the resource.

There are no detailed studies which calculate the capacity credit for each technology in each country in Africa. Therefore, rough estimates based on IRENA (2013a, 2013b, 2015a, 2015b) are used. Solar power is extremely weather sensitive and variable. The capacity credit of centralized PV plants is thus set at 5 per cent. And the capacity credit of wind is different for each country, ranging from 0 to 10 per cent (IRENA 2013a, 2013b, 2015a, 2015b).

In addition, by using technology-specific emissions data provided by the TED platform, the global warming potential of the African power system development is calculated.

\subsubsection{Data sources}

Three of the five regional power pools-WAPP, EAPP, and SAPP-have created power sectordevelopment master plans. Our study is based on those documents. For the CAPP region, publicly available information has been used. Moreover, IRENA's assessments of renewable deployment prospects on the five regional power pool documents that have replicated, updated, and extended the regional master plans' methodologies are used to complete the analysis. Potential data from IRENA, principally for renewable sources, are taken from IRENA's Global Atlas (IRENA 2014).

The economic variables (e.g. GDP per capita, income growth, etc.) are from the ERS International Macroeconomic Data Set (2014). Structural shares of the economy-industry, agriculture, and service values added - are from the UN Statistics Division. Furthermore, projections on industry, transport, service, and agriculture are from UNCTAD's 2015 Report on Economic Development in Africa.

The demographic data (total population, population growth rate, urbanization) are from the World Population Prospects: the 2015 Revision of the United Nations (UN2015).

The number of households and the size of households are based on the World Urbanization Prospects: the 2014 Revision, custom data (UN 2014).

Energy data are from the energy database Enerdata 2015; the World Development Indicators (WDI) 2015 (World Bank 2015); the World Energy Outlook of the International Energy Agency, 2011 (IEA 2011); and the regional master plans. Only the existing, committed plants and planned projects are included in this study. 'Dry-years' hypotheses have been made for all hydropower sites.

Solar data are from the Mines ParisTech dataset and wind data from the Vortex dataset $(9 \mathrm{~km}$ resolution), as reported by IRENA (2013a). Only the projects attached to a moderate/good site, such as in the case of wind (a load factor of 30 per cent), are considered.

Small-scale hydro data are from the United Nations Industrial Development OrganizationECOWAS Centre for Renewable Energy and Energy Efficiency (2010). Biomass data are from IRENA and KTH (2014). 
Information on GHG emissions and environmental is based on Tier 1 emission factors recommended by the Intergovernmental Panel on Climate Change (IPCC) (Penman et al. 2006).

\subsection{Scenarios}

Three variations of sustainable development objectives were developed for each regional pool, along with the reference scenario. These scenarios combine different levels of sustainable electrification policies from both the supply and demand sides.

The reference scenario is compatible with the IRENA renewable energy deployment study adapted from the regional master plan reference scenarios, with the exceptions of the differentiation in household (e.g. rural and urban)/industrial/services and agriculture sectors' electricity demand. Moreover, the Sustainable Energy for All (SE4ALL) policy that assumes an annual growth rate of 0.7 per cent in the potential of the electrified population to achieve universal access by $2030^{6}$ has been modeled.

The second scenario models a deployment of the available renewable energy resources. In this scenario, based on available data on resource potential (committed and planned only) and ongoing transmission projects in the region, the new and additional capacities added are all renewables. However, no supplementary policy or measures to promote renewable energy are modeled.

The last scenarios are designed to increase the demand- and supply-side energy efficiency. The energy efficiency scenarios incorporate technologies and policies that improve power generation. Energy efficiency consists of managing and limiting energy consumption growth (IEA 2014a). Energy efficiency policies can be implemented on both the supply side and the demand side.

Demand-side management of energy efficiency or conservation consists of the design of measures or programmes seeking to reduce electricity demand or use (Taylor et al. 2008). The supply-side management of energy efficiency refers to the actions taken to ensure the efficiency of the power generation system through the different chains, from the generation and transmission to distribution (Taylor et al. 2008). Our demand-side efficiency scenario models the doubling of the rate of improvement of energy efficiency in the countries under investigation. The SE4All objective for this scenario is an annual drop of 2.6 per cent in energy intensity between 2010 and 2030.

From the supply side, high power transmission and distribution (T\&D) losses ${ }^{7}$ affect the electricity availability and system reliability in Africa. This issue is more accurate within the power pools framework. Indeed, in addition to ageing and insufficient transmission and distribution networks, the electricity grids across the region operate on different frequencies and voltages or use different equipment standards and, so, are incompatible with each other and cannot be connected to the transmission systems of neighbouring countries (Jabara et al. 2009).

\footnotetext{
${ }^{6}$ The SE4All is a multi-stakeholder partnership which seeks, by 2030 to be, 'ensuring universal access to modern energy services; doubling the share of renewable energy in the global energy mix; and doubling the rate of improvement in energy efficiency worldwide' (UN 2011). 0.7 per cent is the electrification growth rate over the last couple of years and disclosed in the 'SE4ALL global tracking framework' report. This report, compiled by multiagency experts, states that the universal access will not be fulfilled by 2030 in most of the African countries and it will be lucky to observe on average the same rate of growth in electrification in the coming years.

${ }^{7}$ T\&D losses are a combination of technical losses and non-technical losses (i.e. electricity theft from distribution lines or through meter tampering, theft of distribution equipment, etc.).
} 
The T\&D loss rate in the sub-Saharan region can reach 25 per cent of total electricity consumption. This is double the global average and much higher than the loss rate in many developing countries. This rate is 10 per cent in South Africa and 14 per cent in North Africa (IEA 2014b). These high loss rates increase the unreliability of power systems, undermining their potential to satisfy the electricity needs at reasonable costs (IEA 2014b).

Across SSA, efficiency policies seeking to reduce T\&D losses are taking place. For example, West Africa has engaged reforms to reduce losses from up to 40 per cent currently, to 10 per cent by 2020. Some countries in southern Africa (e.g. South Africa) have managed to reduce T\&D losses by 10 per cent over the past few years. Some countries in East Africa have also made significant improvements during the 2005-11 period. For instance, between 2005 and 2011, distribution losses have decreased from 18 per cent to 16 per cent in Kenya, and from 27 per cent to 10 per cent in Uganda (Eberhard et al. 2013).

The supply-side energy efficiency consists of policies to improve the electricity production and transmission process through the reduction of the transfer capacities and transmission and distribution network losses. In this study, a reduction of 50 per cent in the transmission and distribution losses of the system by 2030 is linearly modeled.

This last couple of scenarios differentiate our study from all the aforementioned existing studies.

Overall, the objective of the elaborated scenarios is to improve electricity access in Africa without increasing GHG emissions.

Lower, yet more realistic assumptions regarding the future developments of the power system, as well as the socioeconomic environment of the region over the coming twenty years, have been made.

Indeed, no ambitious policy has been modeled (e.g. the AfDB 'New Deal' plan launched in Davos in January 2016 that envisages $160 \mathrm{GW}$ of new grid-connected generation capacity and 75 million new off-grid power connections by 2025, a 20 -fold increase from today's numbers). Only the SE4All's three goals, which have already been implemented across the continent since 2012 are simulated. In addition, an annual electrification growth rate of 0.7 per cent, instead of a target of 100 per cent electrification by 2030, is applied (see footnote 3). Moreover, on the renewable energy deployment side, only the existing, committed plants and planned projects are included in the study. Potential future projects, promising sites, and technologies are not considered. ${ }^{8}$

We thus believe that these scenarios are well-suited for the purpose of this study, to quantitatively analyse the current status of power generation in Africa and explore regional resources development towards universal electricity access and the associated emissions.

\section{$5 \quad$ Results and analysis}

Each scenario narrative described above was translated into generation mixes. For each generation mix, the following metrics are analysed: composition of electricity generation, energy resource

\footnotetext{
${ }^{8}$ For details of the planned projects and committed plants, refer to (IRENA 2013a, 2013b, 2015a, 2015b).
} 
diversity, and global warming potential. As such, the scenario comparison will be characterized by the trade-offs between these three metrics.

\subsection{Demand projections}

Electricity demand among the member states of the four power pools is projected to increase almost fourfold in 2040, from 583 in 2015 to 2,172 TW h (see Table 5 and Figure 1).

Currently, more than 78 per cent of the total demand of electricity in the region comes from the industrial sector with almost all of the rest from the residential and agricultural sectors $(9$ per cent and 7 per cent respectively). Within the residential demand segment, urban demand accounts for 71 per cent and rural for 29 per cent.

This mix is projected to change by 2040. Indeed, even if the share of the residential demand in the total demand declines due to the higher increase of demand from the other sectors, in 2040, the residential sector demand will rise in absolute value by 8 per cent. When analysing the total residential electricity demand, it has been forecast that by 2040 , both urban and rural demand will climb by 0.6 TW $h$ and 2.5 TW h respectively.

The industrial sector demand in absolute value, as well as a share of the total demand, will increase. It will represent 89 per cent of the total demand in 2040.

Demands from the services and agricultural sectors are also projected to increase in absolute values by 97 TW h and 19 TW h respectively. Nevertheless, by 2040, the industrial sector will still dominate the total regional electricity consumption.

For the WAPP member states, electricity demand is expected to increase threefold by 2040 to 243 TW h (Figure 2). Most of this demand comes from Nigeria. Among the sectors, the industry will have the largest share of energy demand in 2040 (75 per cent) followed by the agricultural section (16 per cent).

Currently, only 3 per cent of the electricity demand comes from the household sector. This figure will not change much by 2040, when only 3.1 per cent of the total demand will come from the household. Currently, more than 80 per cent of this residential demand comes from urban users. Rural demand is not significant. However, by 2040, the share of rural demand will slightly increase. Detailed sectoral demand by region is shown in Figure A2 in the Appendix.

Electricity demand in CAPP is expected to increase almost fivefold by 2040, boosting the figure from around 19 TW h in 2015 to 95 TW h in 2040 (see Figure 3).

CAPP consumption is dominated by the DRC which accounts for 58 per cent of the total demand, but will comprise 80 per cent of the electricity needs in 2040. The second largest consumer of CAPP is the Republic of Congo with 2.5 per cent of the current demand, but it will account for 6 per cent of the total demand in 2040.

The industry sector is projected to account for 94 per cent of the total demand in 2040 . The current share of household electricity consumption is high (20 per cent). When analysing the projected residential electricity demand, it occurs that by 2040, it will account for only 3 per cent of the total demand. Both of the urban and rural demands are decreasing (Figure A2 in the Appendix).

Demand in EAPP is projected to increase more than fourfold by 2040, boosting the total amount of electricity from around 165 TW h in 2015 to 774 TW h in 2040 (Figure 4). Egypt will account for 65 per cent of the total electricity demand by 2040 with over 500 TW h. However, its share of 
the total demand will decrease between 2015 and 2040 in favour of Kenya and the DRC, which will see their shares increase from 3 to 8 per cent and 5 to 10 per cent, respectively. Ethiopia is the fourth largest consumer of the power pool. In contrast, Burundi, Djibouti, Eritrea, Rwanda, and Somalia will together account for less than 2 per cent of the total.

Demand from the industrial sector will account for the largest share by 2040, reaching 85 per cent. The agriculture sector is the second largest consumer in the region with 7 per cent of the total demand. The residential sector demand is projected at only 5 per cent.

In total values, urban, as well as rural, demands will decrease by $0.5 \mathrm{TW} h$ each. These figures could be explained by the population growth rate that will outpace the growth rate of electrification in some countries. DRC's residential sector is the first consumer of the region, followed by Gabon. The shares of the other countries are relatively low.

Regional demand within SAPP is expected to increase 4.5 times by 2040 from a current level of $237 \mathrm{TW}$ h to 1,061 TW h (Figure 5). The share of consumption of South Africa will decrease from 83 per cent to 66 per cent by 2040. Indeed, since South Africa is already a mature economy, the share of its demand relative to those of the other countries will fall by 2040 . The shares of the demands of Zimbabwe, DRC, and Zambia in the regional total demand will particularly increase (from 5 per cent in 2015 to 11 per cent in 2040 for Zimbabwe, from 4.2 per cent to 7.4 per cent for DRC, and finally from 2.9 per cent to 7.3 per cent for Zambia). Angola and Swaziland have the lowest shares in the total demand of SAPP and their shares are projected to decrease by 2040.

Industrial and residential demands are projected to increase from the current levels by 700,28 , and $1 \mathrm{TW}$ h, respectively.

\subsection{Electricity generation projections}

Generated electricity based on the BAU scenario for all regions is shown in Figure 6 where the different pools SAPP, EAP, WAPP, and CAPP, respectively generated 329, 240, 80, and 29 TW h of electricity in 2015. These productions will increase by more than 1.5 points in 2040 as electricity demand in all the fourth regional pools is increasing. In 2040, generated electricity will reach 520,460, 130 and 46 TW h, respectively in SAPP, EAP, WAPP, and CAPP (Figure 7).

However, despite these rises in the generation quantities (by 58 per cent for SAPP, 92 per cent for EAPP, 63 per cent for WAPP, 60 per cent for CAPP), the energy needs in all the power pools' member states will still not be met by 2040 . Indeed, the electricity demands are projected to be higher compared to the supply for all of the regional pools.

\subsubsection{Regional generation}

Under the BAU scenario, solid fossil fuels (i.e. coal) will still dominate the regional electricity generation in 2040 because of its high share in the SAPP electricity generation (32 per cent of the total production) and because of new coal-fired power plants that will become operational in EAPP in the near future. Natural gas will have the second highest rate out of the total mix of the regional electricity generation (28 per cent).

Hydroelectricity will have the third highest rate of the regional electricity generation mix (23 per cent) because of its high share in the CAPP electricity generation mix.

Besides coal-fired power plant generation, which accounted for 68 per cent of the generation mix in 2015, hydro accounts for 21 per cent in the mix of the SAPP electricity generation. Natural 
gas accounts for 5.8 per cent, the renewables other than hydroelectricity ${ }^{9}$ for 4 per cent, oil for 0.7 per cent, and biomass for 0.4 per cent. The demand pattern will remain the same in 2040, with just a 1 per cent drop in the shares of coal, oil, and natural gas in the total generation mix and a 1 per cent increase in the other renewable sources.

The WAPP electricity mix in 2015 was as follows: 53 per cent for natural gas; 9 per cent for oil; 33 per cent for hydro; and 5 per cent for biomass. The other renewables resources are not significant.

In 2040, the share of hydro in the generation mix will decrease by 7 per cent. Natural gas will also decrease, but by only 1 per cent. Moreover, an increase in the share of biomass in the total electricity generation to 9 per cent will occur.

The electricity generation mix in EAPP is as follows: 69 per cent of natural gas, 1.3 per cent of oil, 20 per cent of hydro, 0.5 per cent of biomass, and 9 per cent of other renewables (geothermal and wind mainly in the EAPP perspective). This mix is projected to be slightly different in 2040, with decreases in the shares of natural gas and hydro that will account for only 50 per cent and 18 per cent, respectively. Rises in the shares of the other forms of renewable energy (16 per cent) and oil (11 per cent) are observed. In addition, an increase from 0 per cent to 3 per cent of the coal share out of the total mix is projected. Indeed, new coal-fired power plants (e.g. based in Kenya) are planned to be launched in the region.

The CAPP region is unique in having almost only hydropower plants generating nearly all the electricity. They account for 91 per cent of the total power generation mix. The shares of the other fuels are 6 per cent for natural gas, 1.8 per cent for oil, and 0.3 per cent for the other renewables. Hydropower will still have the largest share in the CAPP power generation mix in 2040, accounting for 89 per cent. However, an increase in the share of oil by 2.5 per cent is projected.

\subsubsection{The alternative scenarios}

\section{Renewable energy scenario}

Under the renewable energy scenario, hydroelectricity and, more generally, energy from renewable sources will dominate the regional power generation mix (see Figure 8). Hydroelectricity will account for 22 per cent of the generation mix of SAPP and the other forms of renewable energy (e.g. geothermal, small hydro, solar, wind) will account for 26 per cent of the mix. Under this scenario, the share of coal in the electricity mix will stand at only 47 per cent (compared to 68 per cent under the reference scenario).

While the share of hydro is expected to decrease by 7 per cent from 2015 to 2040 under the BAU in the total electricity generation mix of the WAPP, under the renewable scenario, this share will almost double by 2040, standing at 47 per cent. The share of the other renewables (mainly solar) is also projected to increase from 0.01 per cent under the reference scenario to 13 per cent in this scenario, while the share of natural gas and oil will decrease (from 11 to 4 per cent for oil, and from 52 per cent to 26 per cent for natural gas).

The generation mix of the EAP will also encounter important modifications under the renewable energy promotion scenario.

\footnotetext{
${ }^{9}$ This group of fuels includes non-hydro renewables energy namely, solar, wind, geothermal, and small hydro.
} 
Indeed, the share of natural gas in the region mix will decrease by 10 per cent and the share of oil by half. On the contrary, the share of hydro will increase by 18 points. The share of the other renewables will also increase, but by only 1 point.

Given the current high share of renewable energy, principally hydro, the changes in shares of the electricity generation mix of CAPP are low under the renewable scenario. Increases in the hydropower share by 6.5 per cent and natural gas by 2.6 points are observed. Moreover, out of the total generation mix, the share of biomass will increase by 0.5 per cent and the other renewables by 0.1 per cent. A slight decrease in oil by 2.6 points is also projected.

\section{Energy efficiency scenarios}

Under the supply-side energy efficiency scenario, the changes in the electricity generation process of all the power pools are very small (see Figure 9). Compared to the reference scenario, a decrease in the production of CAPP by $4.5 \mathrm{TW} h$ is observed at the hydroelectricity, natural gas, and oil levels $(-3.6,-0.5$, and -0.4 respectively).

For EAPP, this decrease will stand at $-10 \mathrm{TW} h$ in 2040 . Decreases by more than $2.6 \mathrm{TW} h$ for gas, oil, and hydro are projected. Decreases are also projected for the other fuels inputs in the process of electricity generation, but they will be less than $1 \mathrm{TW} h$.

WAPP will encounter a decrease of only $1 \mathrm{TW} h$ while the SAPP decrease will stand only at $0.8 \mathrm{TW}$ h.

Overall, in the supply-side management scenario, energy savings are as much as $17 \mathrm{TW} h$. The highest amount of savings will be made at the hydroelectricity level (-6 TW h) and in the natural gas and oil processes ( $-3 \mathrm{TW} h)$.

The demand-side energy efficiency policy and measures seem more efficient for the regional power system overall, in terms of energy conservation. The highest rate of savings is observed for the EAPP system (-62 TW $h$ in 2040). Decreases are observed in all the processes using the different fuels with the highest share for the hydropower process $(-16 \mathrm{TW} h)$.

SAPP inputs fuels savings will stand at $15 \mathrm{TW} h$ in 2040, under the demand-side energy efficiency. The savings will be particularly important at the coal-fired power plant level ( $-9 \mathrm{TW} h)$, followed by hydropower $(-3 \mathrm{TW} h)$.

The reductions of inputs fuels in the generation process of CAPP under this scenario are -7.9 TW $h$. The highest saving rate will be for the coal-fired power plant that will stand at $9 \mathrm{TW} h$. The hydroelectricity generation process will save 3 TW $h$ under the demand-side energy efficiency scenario.

Inputs fuels in the WAPP generation mix will decrease by 18, 7, and $6 \mathrm{TW}$ h respectively for natural gas, hydro, and biomass. Overall, WAPP will save a total of 34 TW h by 2040.

Under the demand-side energy efficiency scenario, the electricity generation processes of the four power pools will allow savings of $119 \mathrm{TW}$ h (see Figure 10).

\subsection{Environmental perspective}

Greenhouse gases (GHG) emissions that are produced from electricity generation by the different power pools and for the various scenarios are displayed in Table 6. 
The average growth rate of GHG emissions is 88 per cent from 2015 to 2040 for the four power pools under the BAU scenario. For EAPP and CAPP, this growth will become more than 100 per cent by 2040 (123 per cent for each).

Indeed, even if hydropower will account for a large share in the total generation mix of CAPP in 2040 , an increase in the share of oil gas by 2040 is projected $(+2.5$ per cent), which will increase the GHG emissions of the region.

For EAPP, increases in the shares of oil and coal in the total electricity generation by 11 per cent and 3 per cent respectively in 2040 are projected, explaining the rise in GHG emissions. Moreover, the total productions in these two power pools are projected to steadily increase from 2015 to 2040 .

Nevertheless, by considering only the carbon dioxide emissions, the rates of increase are smaller: a 69 per cent increase in total emissions, 119 per cent increase for CAPP, and 116 per cent for EAPP. These figures are explained by the Biogenic $\mathrm{CO}_{2}$ emissions, associated with the biomass cogeneration. Indeed, Biogenic $\mathrm{CO}_{2}$ emissions are those related to the natural carbon cycle or to the harvest, digestion, combustion, decomposition, fermentation, or processing of biologically based materials (EPA 2014).

As biomass usages in electricity generation are increasing in the region, the Biogenic $\mathrm{CO}_{2}$ emissions will increase, as well. This is particularly obvious in the alternative scenario: the renewable promotion scenario.

Under the renewable scenario, the GHG emissions will decrease by 2040 for all the power pools in the region. The regional total emissions under this scenario will decrease by 3.3 per cent in 2015 and by 6 per cent in 2040. Those reductions in the emissions are even higher if one considers only the 3.9 per cent reduction in $\mathrm{CO}_{2}$ in 2015 and 7.7 per cent in 2040. Under this scenario, some committed projects on generating capacity addition from biomass will become operational (e.g. in South Africa, Somalia, Mozambique, Benin, Guinea, etc.). This will result in an increase of Biogenic $\mathrm{CO}_{2}$ emissions in the region, lowering the potential emissions reductions associated with the switch to more clean energy sources.

Overall, under this scenario, the reductions of $\mathrm{CO}_{2}$ emissions in 2040 are the most significant in EAPP and WAPP (-22 per cent). Only 1.7 per cent of reductions of $\mathrm{CO}_{2}$ emissions is observed for SAPP and no reduction at all is observed for CAPP.

The energy efficiency scenarios both on the demand side, as well as the supply-side management measures, allow for reductions in the total GHG emissions for the entire regional power pools.

Overall, between 2015 and 2040, the GHG emissions in the region will increase regardless of the scenario due to the increase in power generation associated with the increase of electricity demand in the region. Under the energy efficiency scenario, and with demand-side management policies, the reductions of GHG emissions will reach 9 per cent in 2040, as compared to the BAU scenario. The regional reductions under this scenario in 2040 will be: 31 per cent, 18 per cent, 3 per cent, and 39 per cent for WAPP, EAPP, SAPP, and CAPP, respectively.

Supply-side energy efficiency policies will allow for decreases in the GHG emissions by 20 per cent in 2040.

Under the supply-side energy efficiency policies, the reductions in the regional electrical systems in 2040 will stand at 21, 22, 19, and 34 per cent for WAPP, EAPP, SAPP, and CAPP, respectively. 
This paper develops an electricity supply-demand scenarios-based model to identify the most efficient and environmentally friendly way for the African power systems development and looks at the feasibility and consequences on the universal access to electricity of African countries.

Scenarios-based analysis of the electricity system was conducted from the technological, economic, and environmental perspectives, using the scenario methodology developed by Schwartz in the context of the energy-economic modeling platform 'Long-range Energy Alternative Planning'.

The results show that under the BAU, we will face both increases in primary resource requirements and GHG emissions. However, despite the increases in electricity generation, even if the universal access to modern energy will not be fulfilled by either 2030 or 2040 , total electricity will increase as much as fourfold, making the supply insufficient to meet the demand. In the final year of projections, the total demand of electricity for the four regional power pools will be 2,173 TW $\mathrm{h}$ while the production will stand at 1,155 TW $\mathrm{h}$. The unmet demand of the region will then be 1,018 TW h. Therefore, almost half of the electricity needs in the region will not be met.

Consequently, the current national and global energy policies for the electrification of Africa are not sufficient to allow for an alleviation of electricity poverty by 2040. In other words, with the current electrification rate, more than two decades will be required to end energy poverty in SSA.

To investigate the methods to meet this demand in a sustainable way, three alternative scenarios based on the reference scenario are designed.

First, a renewable energy promotion scenario, which assumes that the future capacity expansion of the regional electricity network will be made by adding only renewable energy sources, is designed. The result is an increase in the quantity of generated electricity by 44 per cent in 2040, compared to that of the BAU.

Therefore, by using their vast and largely untapped renewable energy potential, sub-Saharan countries could provide electricity for all more rapidly. Nevertheless, the ongoing renewable energy policies will be insufficient to meet the total electricity needs by 2040. There will still be an unmet demand that will stand at about $510 \mathrm{TW}$ h.

In addition, the current projects which seek to promote hydro and biomass mainly as renewable sources of energy will fail to reach the objective of sustainable electrification in the region as the GHG emissions under the renewable scenario will increase. Indeed, if the general decrease in the fossil fuel consumption in the generation mix leads to GHG emissions reductions by 6 per cent and $\mathrm{CO}_{2}$ reductions by 7.7 per cent, increases of biomass energy in the generation mix of some countries under this scenario may jeopardize the potential of the emissions reductions.

Overall, policies for accelerated deployment of renewable energy are needed, but a careful selection of renewable energy technologies that are appropriate to Africa is also primordial as they are not equally sustainable. Some biomass power and cogeneration projects have the potential to conflict with climate change mitigation goals.

Second, two scenarios that are variations of energy efficiency policies have been tested as alternative sustainable scenarios to meet SSA's energy demand. The first one is related to demandside energy efficiency measures that seek to reduce the energy intensity of energy consumption by doubling the rate of improvement in energy efficiency. Under this scenario, the four power pools 
would save 119 TW h. Moreover, under this scenario, a total reduction of 65 million metric tonnes of GHGs is realized.

In addition to the demand-side efficiency measurements, supply-side energy efficiency has been simulated. A reduction by half of the losses that occur along the chain of transmission and distribution of electricity generation systems to increase the supply-side energy efficiency has led to energy savings of $60 \mathrm{TW} h$ and emissions reductions of 147 million metric tonnes of GHGs.

Hence, energy efficiency and conservation measures that will improve electricity efficiency from both the demand side and supply side are the best options for the region to tackle issues, such as energy shortages, energy poverty, and energy security, as well as those related to climate change (see Table A3 for a comparative summary of the four scenarios).

Energy conservation mechanisms will help limit energy demand by either promoting the usage of energy-efficient appliances and equipment or by changing negative consumer behaviour. The improvement of the efficiency of electricity generation through better equipment will help reduce the generation, transmission, and distribution loss rates, lower operating costs across industries, strengthen energy security, and reduce GHG emissions. In addition, energy efficiency has the potential to impact SSA sustainable economic development.

However, due to the limited understanding of energy efficiency as an energy resource and the little awareness of the benefits it can provide, energy efficiency has received limited attention in SSA in the past. African countries are often largely more preoccupied with the immediate problems of meeting the pressing demands for a minimum level of modern energy services for the majority of their populations and the international community is more interested in financing the development of renewable energy than energy efficiency in SSA. Hence, energy efficiency in SSA is given a low priority and efforts are largely towards the extension and increase of electricity generation rather than energy efficiency.

Nevertheless, it should be noted that many countries have recently undertaken some small-scale energy efficiency projects. However, these projects face a variety of market and non-market barriers, including poor regulatory environments and governance issues that undermine the economic incentives to invest in energy efficiency and impede the private sector energy efficiency market, lack of a local trained workforce to undertake new energy efficiency projects, as well as a lack of access to financing for energy efficiency projects. Policies to overcome these barriers and scale up energy efficiency measures include the institution of cost-reflective electricity tariffs and lifeline tariffs for the low-level income populations that will help ensure that the poor have access to electricity and that power utilities have a sustainable business model, investments in local workforce training, and access to financing mechanisms in conjunction with the international climate finance mechanisms.

The long-term climate change objectives are incompatible with the BAU trajectory of SSA that will lead to an 88 per cent increase in its emissions by 2040. It is in the global interest to increase adaptation assistance, as well as accelerate the transfer of energy efficiency technologies that will help meet the growing demand while reducing greenhouses gas emissions.

Overall, the study shows that more ambitious measures to increase the electrification rate as much as 40-fold on today's number are needed for an alleviation of electricity poverty in SSA. This could be achieved through an increase of both the number of new grid-connected power generation capacity and off-grid renewable power solutions in addition to demand and supply-side energy efficiency measures. 


\section{References}

AfDB (African Development Bank) (2008). Proposals for a Clean Energy Investment Framework. Tunis: Role of the African Development Bank Group. Abidjan: AfDB.

Amina, M., and V.S. Kodogiannis (2011). 'Load Forecasting Using Fuzzy Wavelet Neural Networks'. In Conference Publication: Fuzzy Systems (FUZZ), 2011 IEEE International Conference, 27-30 June: 1033-40. doi: http:// dx.doi.org/10.1109/FUZZY.2011.6007492.

Bazilian, M., P. Nussbaumer, H.-H. Rogner, A. Brew-Hammond, V. Foster, E. Williams, M. Howells, P. Niyongabo, L. Musaba, B. Ó Gallachóir, M. Radka, and D.M. Kammen (2012). 'Access Scenarios to 2030 for the Power Sector in Sub-Saharan Africa'. Utilities Policy, 20: 116.

Bhattacharyya, S.C., and G.R Timilsina (2010). "Modelling energy demand for developing countries: Are specific features adequately captured'. Energy Policy, 38(4): 1979-90.

Castellano, A, A. Kendall, M. Nikomarov, and T. Swemmer (2015). 'Brighter Africa: The Growth Potential of the sub-Saharan Electricity Sector’. McKinsey Global Institute; 2015 (Electric Power \& Natural Gas, February). Available at: file://C:/Users/George/Downloads/Brighter_Africa-The_growth_potential_of_the_subSaharan_electricity_sector $\% 20(1)$.pdf.

Chakravarty, S, and M. Tavoni (2013). 'Energy Poverty Alleviation and Climate Change Mitigation: Is There a Trade-off?'. Energy Economics, 40: S67-73.

EAPP (Eastern Africa Power Pool). (2014). EAPP Regional Power System Master Plan Volume I: Main Report. 2014. Addis Ababa: EAPP.

Eberhard, A, O, Rosnes, M. Shkaratan, H. Vennemo (2011). Africa's Power Infrastructure: Investment, Integration, Efficiency. Washington, DC: World Bank Publications.

Eberhard, A., O. Rosnes, M. Shkaratan, and H. Vennemo (2013). Africa's Power Infrastructure. Washington, DC: World Bank.

Enerdata (2015). 'Total Energy Consumption 2015'. [Online.] Available at: https://yearbook.enerdata.net/.

ERS (Economic Research Service (2014). 'International Macroeconomic Data Set'. [Online.] Available at: https:// catalog.data.gov/dataset/international-macroeconomic-data-set.

EPA (United States Environmental Protection Agency) (2014). 'Framework for Assessing Biogenic $\mathrm{CO}_{2}$ Emissions from Stationary Sources'. United States Environmental Protection Agency, Office of Air and Radiation Office of Atmospheric Programs, Climate Change Division. Available at: https://www3.epa.gov/climatechange/downloads/Framework-forAssessing-Biogenic-CO2-Emissions.pdf.

Gnansounou, E, H. Bayem, D. Bednyagin, and J. Dong (2007). 'Strategies for Regional Integration of Electricity Supply in West Africa'. Energy Policy, 35: 4142-53.

Government of Canada (n.d.). 'Natural Resources Canada: RETScreen'. [Online.] Available at: http://www.nrcan.gc.ca/energy/software-tools/7465.

Hall, L.M.H, and A.R. Buckley (2016). 'A Review of Energy Systems Models in the UK: Prevalent Usage and Categorization’. Applied Energy, 169(2016): 607-28.

Heaps, C.G. (2016). 'Long-range Energy Alternatives Planning (LEAP) System'. [Software Version: 2015.0.30]. Somerville, MA: Stockholm Environment Institute. Available at: https://www.energycommunity.org. 
Herbst, A, F. Toro, F. Reitze, and E. Jochem (2012). 'Introduction to Energy Systems Modelling'. Swiss Journal of Economics and Statistics, 148 (2): 111-35.

Howells, M.I., T. Alfstad, D.G. Victor, G. Goldstein, and U. Remme (2005). 'A Model of Household Energy Services in a Low-income Rural African Village’. Energy Policy, 33: 183351.

ICA (Infrastructure Consortium for Africa) (2011). Regional Power Status in African Power Pools: Report. Tunis Belvédère: ICA.

IEA (International Energy Agency) (2011). World Energy Outlook 2011. Paris: IEA.

IEA (International Energy Agency) (2014a). Energy Efficiency Indicators: Essentials for Policy Making. Paris: IEA.

IEA (International Energy Agency) (2014b). World Energy Outlook 2014-Africa Energy Outlook: A Focus on Energy Prospects in Sub-Saharan Africa. Paris: Organisation for Economic Co-operation and Development.

IRENA (International Renewable Energy Agency) (2013a). South African Power Pool Planning and Prospects for Renewable Energy. Abu Dhabi/Bonn: IRENA.

IRENA (International Renewable Energy Agency) (2013b). West African Power Pool: Planning and Prospects for Renewable Energy. Abu Dhabi/Bonn: IRENA.

IRENA (International Renewable Energy Agency) (2014). 'The Global Atlas'. [Online.] Available at: http:/ /globalatlas.irena.org/ (accessed in May 2016).

IRENA (International Renewable Energy Agency) (2015a). Central African Power Pool: Planning and Prospects for Renewable Energy. Abu Dhabi/Bonn: IRENA.

IRENA (International Renewable Energy Agency) (2015b). East African Power Pool: Planning and Prospects for Renewable Energy. Abu Dhabi/Bonn: IRENA.

IRENA (International Renewable Energy Agency) (2015c). Africa Power Sector: Planning and Prospects for Renewable Energy. Abu Dhabi/Bonn: IRENA.

IRENA (International Renewable Energy Agency) and KTH (Royal Institute of Technology Sweden) (2014). 'Estimating the Renewable Energy Potential in Africa'. Available at: http:// www.irena.org/DocumentDownloads/Publications/IRENA_Africa_Resource_ Potential_Aug2014.pdf (accessed in May 2016).

Jabara, C., M. Ferrantino, I. Wohl, J. Peterson, D. Luther, M. Simone, D. Cook, B. Lynch, P. Stone, D. Heuschel, J. Fry, and L. Bloodgood (2009). Sub-Saharan Africa: Effects of Infrastructure Conditions on Export Competitiveness, Third Annual Report. Washington, DC: United States International Trade Commission.

Mcpherson, M., and B.W. Karney (2014). 'Long-term Scenario Alternatives and their Implications: LEAP Model Application of Panama’s Electricity Sector'. Energy Policy; 68: 146-57.

Nexant (2004). West Africa Regional Transmission Stability Report. Washington, DC: USAID, ECOWAS.

Nussbaumer, P, M. Bazilian, and V. Modi (2012). 'Measuring Energy Poverty: Focusing on What Matters'. Renewable and Sustainable Energy Reviews, 16(1): 231-43.

Ouedraogo, N. (2012). 'Energy Consumption and Economic Growth: Evidence from ECOWAS'. Energy Economics, 36: 637-47.

Ouedraogo, N. (2013). 'Energy Consumption and Human Development: Evidence from a Panel Cointegration and Error Correction Model'. Energy, 63: 28-41. 
Pachauri, S., N. Rao, Y. Nagai, and K. Riahi (2012). Access to Modern Energy: Assessment and Outlook for Developing and Emerging Region. Laxenburg: IIASA.

Pachauri, S, B.J. Van Ruijven, Y. Nagai, K. Riahi, D.P. Van Vuuren, A. Brew-Hammond, and N. Nakicenovic (2013). 'Pathways to Achieve Universal Household Access to Modern Energy by 2030'. Environmental Research Letters, 8(2).

Panos E., H. Turton, M. Densing, and K. Volkart (2015). 'Powering the Growth of Sub-Saharan Africa: The Jazz and Symphony Scenarios of World Energy Council'. Energy for Sustainable Development, 26: 14-33.

Panos, E, M. Densing, and K. Volkart (2016). 'Access to Electricity in the World Energy Council's Global Energy Scenarios: An Outlook for Developing Regions Until 2030’. Energy Strategy Reviews, 9: 28-49.

Penman, J., M. Gytarsky, T. Hiraishi, W. Irving, and T. Krug (2006). 'IPCC Guidelines for National Greenhouse Gas Inventories'. Available at: http://www. ipccnggip.iges.or.jp/public/2006gl/pdf/0_Overview/V0_1_Overview.pdf (accessed in May 2016).

PIDA (Programme for Infrastructure Development in Africa) (2010). 'Africa's Infrastructure Outlooks 2040'. Available at: http://www.foresightfordevelopment.org/sobipro/55/124-africas-infrastructure-outlooks2040 (accessed on 1 July 2016).

REN21 (Renewable Energy Policy Network for the $21^{\text {st }}$ Century) (2014). 'ECOWAS Renewable Energy and Energy Efficiency Status Report'. Available at: http:// www.ren21.net/Portals/0/documents/activities/Regionalpercent20Reports/ECOWAS_E N.pdf (accessed in May 2016).

Riahi, K, F. Dentener, D. Gielen, A. Grubler, J. Jewell, Z. Klimont, V. Krey, D. McCollum, S. Pachauri, S. Rao, B. van Ruijven, D.P. van Vuuren, and C. Wilson (2011). 'Energy Pathways for Sustainable Development'. In GEA (ed), The Global Energy Assessment: Toward a More Sustainable Future. Laxenburg and Cambridge: IIASA, Cambridge University Press.

Rogan, F., C.J. Cahill, H.E. Daly, D. Dineen, J.P. Deane, C. Heaps, M. Welsch, M. Howells, M. Bazilian, and B.P. Ó Gallachóir (2014). 'LEAPs and Bounds—an Energy Demand and Constraint Optimised Model of the Irish Energy System’. Energy Efficiency, 7: 441.

Rosnes, O., and H. Vennemo (2012). 'The Cost of Providing Electricity to Africa'. Energy Economics, 34: 1318-28.

Santos, P.J., A.G. Martins, and A.J. Pires (2007). 'Designing the Input Vector to ANN-based Models for Short-term Load Forecast in Electricity Distribution Systems'. International Journal of Electrical Power \& Energy Systems, 29(1): 338-47.

SAPP (Southern African Power Pool) (2007). SAPP Regional Generation and Transmission Expansion Plan Study. Draft Report, Volume 2, Main Report. Harare: SAPP.

SAPP (Southern African Power Pool) (2009). SAPP Regional Generation and Transmission Explansion Plan Study. Final Report, Volume 2. Harare: SAPP

Schade, W., E. Jochem, T. Barker, G. Catenazzi, W. Eichhammer, T. Fleiter, A. Held, N. Helfrich, M. Jakob, P. Criqui, S. Mima, L. Quandt, A. Peters, M. Ragwitz, U. Reiter, F. Reitze, M. Schelhaas, S. Scrieciu and H. Turton. (2009). 'ADAM 2-degree Scenario for Europe-Policies and Impacts'. Deliverable D-M1.3 of ADAM (Adaptation and Mitigation Strategies: Supporting European Climate Policy). Project Co-funded by European Commission 6th RTD Programme. Karlsruhe: ADAM. 
SEI (Stockholm Environment Institute) (2006). LEAP: Long Range Energy Alternative Planning System-User Guide. Boston, MA: SEI. Available at: www.energycommunity.org/documents/Leap2006UserGuideEnglish.pdf.

Semertzidis, T. (2015). 'Can Energy Systems Models Address the Resource Nexus?'. Energy Procedia, 83: 279-88.

Shukla, P.R. (1995). 'Greenhouse Gas Models and Abatement Costs for Developing Nations: Critical Assessment’. Energy Policy, 8: 677-87.

SNC Lavalin International Inc. and Parsons Brinkerhoff (2011). Eastern Africa Power Pool (EAPP) and East African Community (EAC)-Regional Power System Master Plan and Grid Code Study-Final Master Plan Report Volume I.

Suhono, S. (2015). 'Long-term Electricity Demand Forecasting of Sumatera System Based on Electricity Consumption Intensity and Indonesia Population Projection 2010-2035'. Energy Procedia, 68(April): 455-62.

Taliotis, C., M. Bazilian, M. Welsch, D. Gielen, and M. Howells (2014). 'Grand Inga to Power Africa: Hydropower Development Scenarios to 2035’. Energy Strategy Reviews, 4: 1-10.

Taliotis C, A. Miketa, M. Howells, S. Hermann, M. Welsch, O. Broad, H. Rogner, M. Bazilian, and D. Gielen (2014). 'An Indicative Assessment of Investment Opportunities in the African Electricity Supply Sector'. Journal of Energy in South Africa, 25(1): 02-12.

Taliotis, C., A. Shivakuma, E. Ramos, M. Howells, D. Mentis, V. Sridharan, O. Broad, and L. Mofor (2016). 'An Indicative Analysis of Investment Opportunities in the African Electricity Supply Sector-Using TEMBA (the Electricity Model Base for Africa)'. Energy for Sustainable Development, 31: 50-66.

Taylor, R.P., C. Govindarajalu, J. Levin, A.S. Meyer, and W.A. Ward (2008). Financing Energy Efficiency: Lessons from Brazil, China, India and beyond. Washington, DC: World Bank.

Timmerman, J., C. Deckmynb, L. Vandeveldeb, and G. Van Eetveldea (2014). 'Towards Low Carbon Business Park Energy Systems: Classification of Techno-economic Energy Models'. Energy, 75(2014): 68-80.

UN (United Nations) 2014. World Urbanization Prospects: The 2014 Revision. New York, NY: Department of Economic and Social Affairs, UN.

UN (United Nations) 2015. World Population Prospects: The 2015 Revision. New York, NY: Department of Economic and Social Affairs, UN.

UNCTAD (United Nations Conference on Trade and Development) (2015). Economic Development in Africa Report 2015: Unlocking the Potential of Africa's Services Trade for Growth and Development. New York, NY: UNCTAD.

Urban, F., R.M.J. Benders, and H.C. Moll (2007). 'Modelling Energy Systems for Developing Countries'. Energy Policy, 35(2007): 3473-82.

WAPP (West African Power Pool) (2011). Update of the ECOWAS Revised Master Plan for the Generation and Transmission of Electrical Energy. Cotonou: WAPP.

World Bank (2015). World Development Indicators 2015. Washington, DC: World Bank. 


\section{Sources of data}

Various statistical publications from the United Nations and other international organizations have been used.

United Nations Human Settlements Programme (UNHabitat), Global Urban Indicators Database 2012.

United Nations Human Settlements Programme (UNHabitat), Urban Info 2010. These include: United Nations, Department of Economic and Social Affairs, Population Division (2010); World Population Prospects: The 2009 Revision, United Nations, New York United Nations; Department of Economic and Social Affairs, Population Division (2012) World Urbanization Prospects: The 2011 Revision, United Nations, New York.

World Bank (2001). World Development Indicators 2001. Washington, DC: World Bank.

World Bank (2004). World Development Indicators 2004. Washington (DC): World Bank.

World Bank (2006). World Development report 2006. Washington (DC): World Bank.

World Bank (2012). World Development Indicators 2012. Washington (DC): World Bank.

World Bank. (2012). World development indicators online database $<$ http://data.worldbank.org/indicator>

World Health Organization (WHO) (2004). World Report on road traffic injury prevention 2004. Geneva: WHO.

World Health Organization (WHO) (2014). Global status report on road safety 2013. Geneva: WHO.

World Health Organization (WHO) and United Nations Children's Fund (UNICEF) Joint Monitoring Programme for Water Supply and Sanitation (JMP) (2012). Progress on sanitation and drinking-water 2012 update, WHO and UNICEF, Geneva and New York. $<$ www.unicef.org/media/files/ JMPreport2012.pdf>. 


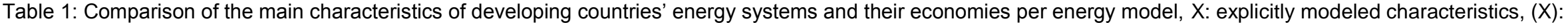
implicitly modeled characteristics

\begin{tabular}{|c|c|c|c|c|c|c|c|c|c|c|c|}
\hline \multirow[t]{2}{*}{ Model } & \multicolumn{11}{|c|}{ Main characteristics of developing country's energy systems and economies } \\
\hline & $\begin{array}{l}\text { Performance } \\
\text { of power } \\
\text { sector }\end{array}$ & $\begin{array}{l}\text { Supply } \\
\text { shortages }\end{array}$ & Electrification & $\begin{array}{l}\text { Traditional } \\
\text { biofuels }\end{array}$ & $\begin{array}{l}\text { Urban-rural } \\
\text { divide/ } \\
\text { urbanization }\end{array}$ & $\begin{array}{l}\text { Informal } \\
\text { economy }\end{array}$ & $\begin{array}{l}\text { Structural } \\
\text { economic } \\
\text { change }\end{array}$ & $\begin{array}{l}\text { Investment } \\
\text { decisions }\end{array}$ & Subsidies & $\begin{array}{l}\text { Other } \\
\text { features }\end{array}$ & $\begin{array}{l}\text { Specification of other } \\
\text { features }\end{array}$ \\
\hline $\begin{array}{l}\text { Global energy } \\
\text { environment economy } \\
\text { (E3MG) }\end{array}$ & & & $(\mathrm{x})$ & & & & $(\mathrm{x})$ & $x$ & $x$ & $x$ & $\begin{array}{l}\text { Emission Trading (ET), } \\
\text { limited assessment of } \\
\text { renewable energies (RE) }\end{array}$ \\
\hline $\begin{array}{l}\text { (TARGETS-IMAGE Energy } \\
\text { Regional Model) } \\
\text { (IMAGE/TIMER) }\end{array}$ & & & $(\mathrm{x})$ & & $x$ & $(\mathrm{x})$ & & & & $\mathrm{x}$ & $\begin{array}{l}\text { Clean Development } \\
\text { Mechanism (CDM), ET, } \\
\text { wide assessment of RE }\end{array}$ \\
\hline $\begin{array}{l}\text { Long-range Energy } \\
\text { Alternatives Planning system } \\
\text { (LEAP) }\end{array}$ & $(\mathrm{x})$ & & $\mathrm{x}$ & $\mathrm{x}$ & $(\mathrm{x})$ & & & & $(\mathrm{x})$ & $\mathrm{x}$ & $\begin{array}{l}\text { Indiv. ass. per country, ET, } \\
\text { CDM, RE, rural energy } \\
\text { programmes }\end{array}$ \\
\hline $\begin{array}{l}\text { Model for the Analysis of } \\
\text { Energy Demand (MAED) }\end{array}$ & $x$ & & $\mathrm{x}$ & & $(\mathrm{x})$ & & $x$ & & & $(\mathrm{x})$ & Limited assessment of RE \\
\hline $\begin{array}{l}\text { Market al location model } \\
\text { (MARKA) }\end{array}$ & & & $\mathrm{x}$ & $\mathrm{x}$ & $x$ & & & & $(x)$ & $\mathrm{x}$ & $\mathrm{ET}, \mathrm{CDM}, \mathrm{RE}$ \\
\hline $\begin{array}{l}\text { Model for Energy Supply } \\
\text { Strategy Alternatives and their } \\
\text { General Environmental impact } \\
\text { (MESSAGE) }\end{array}$ & & & $\mathrm{x}$ & $x$ & $(\mathrm{x})$ & & $x$ & & $(\mathrm{x})$ & & $\mathrm{ET}, \mathrm{CDM}, \mathrm{RE}$ \\
\hline $\begin{array}{l}\text { Open Source Energy } \\
\text { Modeling System } \\
\text { (OSeMOSYS) }\end{array}$ & & & $\mathrm{x}$ & & & & & $\mathrm{x}$ & & $\mathrm{x}$ & $\mathrm{ET}, \mathrm{CDM}, \mathrm{RE}$ \\
\hline $\begin{array}{l}\text { Planning of the Electric } \\
\text { Power Generating System } \\
\text { Programme (PLANELEC) }\end{array}$ & & & $\mathrm{x}$ & & & & & $\mathrm{x}$ & & $\mathrm{x}$ & $\mathrm{ET}, \mathrm{RE}$ \\
\hline $\begin{array}{l}\text { Prospective Outlook on } \\
\text { Long-term Energy Systems } \\
\text { (POLES) }\end{array}$ & $(\mathrm{x})$ & & $\mathrm{x}$ & & & & & $\mathrm{x}$ & $(\mathrm{x})$ & $\mathrm{x}$ & $\mathrm{ET}, \mathrm{CDM}, \mathrm{RE}$ \\
\hline PowerPlan & $\mathrm{x}$ & $x$ & $(\mathrm{x})$ & & & & & & & $\mathrm{x}$ & CDM, RE \\
\hline $\begin{array}{l}\text { International Clean } \\
\text { Energy Project Analysis Software } \\
\text { (RETScreen) }\end{array}$ & & & $\mathrm{x}$ & $\mathrm{x}$ & $x$ & & & $(\mathrm{x})$ & $(\mathrm{x})$ & $\mathrm{x}$ & $\begin{array}{l}\text { ET, CDM, RE, off-grid RE } \\
\text { systems }\end{array}$ \\
\hline $\begin{array}{l}\text { Wien Automatic System } \\
\text { Planner (WASP) }\end{array}$ & $(\mathrm{x})$ & $(\mathrm{x})$ & $(\mathrm{x})$ & & & & & $\mathrm{x}$ & & $\mathrm{x}$ & $\begin{array}{l}\text { Environmental emission } \\
\text { ass. }\end{array}$ \\
\hline $\begin{array}{l}\text { World Energy Model } \\
\text { (WEM) }\end{array}$ & & & $\mathrm{x}$ & $x$ & $x$ & & & $(\mathrm{x})$ & $(x)$ & $\mathrm{x}$ & $\begin{array}{l}\text { Indiv. ass. per country, ET, } \\
\text { CDM, RE, focus on energy } \\
\text { and poverty }\end{array}$ \\
\hline
\end{tabular}

Source: Based on Urban et al. (2007) and Hall and Buckley (2016). 
Table 2: Summary of the literature of electricity demand forecasting in Africa

\begin{tabular}{|c|c|c|c|}
\hline & Forecasting period & Model & $\begin{array}{l}\text { Estimated electricity } \\
\text { demand for the last year } \\
\text { of the study }\end{array}$ \\
\hline Howells et al. (2005) & 2002-2018 & MARKAL/TIMES & $\begin{array}{l}\text { South Africa: } 7.10-4 \\
\text { TWh }\end{array}$ \\
\hline Gnansounou et al. (2007) & $2007-2030$ & PLANELEC-Pro & WAPP: 160 TWh \\
\hline Eberhard et al. (2011) & $2005-2015$ & & SSA: 680 TWh \\
\hline \multirow{2}{*}{$\begin{array}{l}\text { Rosnes and Vennemo } \\
\text { (2012) }\end{array}$} & 2005-2015 & Linear programming & SAPP: 397 TWh \\
\hline & & optimization model & $\begin{array}{l}\text { EAPP: } 169 \text { TWh } \\
\text { WAPP: } 94 \text { TWh } \\
\text { CAPP: } 20 \text { TWh } \\
\text { SSA: } 683 \text { TWh }\end{array}$ \\
\hline Bazilian et al. (2012) & $2008-2030$ & Heuristics & $\begin{array}{l}\text { SSA (excluding South } \\
\text { Africa): } 1,390 \text { (UN } \\
\text { population medium } \\
\text { variant scenario) } \\
1,593 \text { TWh (constant } \\
\text { fertility scenario) }\end{array}$ \\
\hline $\begin{array}{l}\text { Chakravartyand Tavoni } \\
\text { (2013) }\end{array}$ & 2009-2030 & $\begin{array}{l}\text { IEA's World Energy Model } \\
\text { (WEM) }\end{array}$ & Africa: 2638 TWh \\
\hline \multirow{2}{*}{$\begin{array}{l}\text { Taliotis, Bazilian et al. } \\
\text { (2014), Taliotis, Miketa et } \\
\text { al. (2014) }\end{array}$} & 2008-2030 & OSeMOSYS & North Africa: $700 \mathrm{TWh}$ \\
\hline & & & $\begin{array}{l}\text { West Africa: } 180 \text { TWh } \\
\text { Central Africa1: } 60 \text { TWh } \\
\text { Southern Africa: } 750 \\
\text { TWh } \\
\text { Eastern Africa: } 200 \text { TWh }\end{array}$ \\
\hline Panos et al.(2016) & 2010-2030 & $\begin{array}{l}\text { GMM MARKAL under the } \\
\text { WEC/PSI }\end{array}$ & SSA: 850 TWh \\
\hline Taliotis et al. (2016) & 2015-2040 & OSeMOSYS & $\begin{array}{l}\text { North Africa: } 1,250 \mathrm{TWh} \\
\text { WAPP: } 350 \mathrm{TWh} \\
\text { SAPP: } 650 \mathrm{TWh} \\
\text { EAPP: } 350 \mathrm{TWh} \\
\text { CAPP: } 100 \mathrm{TWh} \\
\text { Africa: } 2,700 \mathrm{TWh}\end{array}$ \\
\hline The present study (2016) & $2015-2040$ & LEAP & $\begin{array}{l}\text { WAPP: } 243 \text { TWh } \\
\text {-SAPP: } 1,061 \mathrm{TWh} \\
\text {-EAPP: } 774 \mathrm{TWh} \\
\text {-CAPP: } 95 \mathrm{TWh} \\
\text { SSA: } 2,172 \mathrm{TWh}\end{array}$ \\
\hline \multirow[t]{2}{*}{ IRENA (2015) } & $\begin{array}{l}2010-2050 \text { with a focus } \\
\text { on } 2010-2030\end{array}$ & MESSAGE & -WAPP: 250 TWh \\
\hline & & & $\begin{array}{l}\text {-SAPP:750 TWh } \\
\text {-EAPP: } 500 \text { TWh } \\
\text {-CAPP: } 90 \text { TWh } \\
\text {-COMELEC: } 980 \text { TWh }\end{array}$ \\
\hline Castellano et al. (2015) & 2010-2040 & Demand-driven approach ${ }^{a}$ & SSA: 1,600 TWh \\
\hline WAPP (2011) & 2011-2030 & n.a. & $\begin{array}{l}\text { WAPP: } 228.6 \text { TWh } \\
\text { 243.9 TWh (with mines) }\end{array}$ \\
\hline SAPP (2007) & $\begin{array}{l}\text { 2007-2030 Adapted in } \\
2011 \text { and } 2012\end{array}$ & n.a & \\
\hline $\begin{array}{l}\text { SNC Lavalin International } \\
\text { Inc and Parsons } \\
\text { Brinkerhoff (2011), EAPP } \\
\text { (2014) }\end{array}$ & $2015-2040$ & BALMOREL ${ }^{\mathrm{b}}$ model & EAPP: 1,390 TWh \\
\hline IEA (2014) & 2010-2040 & $\begin{array}{l}\text { IEA's World Energy Model } \\
\text { (WEM) }\end{array}$ & $\begin{array}{l}\text {-Africa : 1,869 TWh } \\
\text {-SSA: 1,297 TWh } \\
\text {-North Africa: } 572 \text { TWh } \\
\text {-West Africa: } 417 \text { TWh }\end{array}$ \\
\hline
\end{tabular}




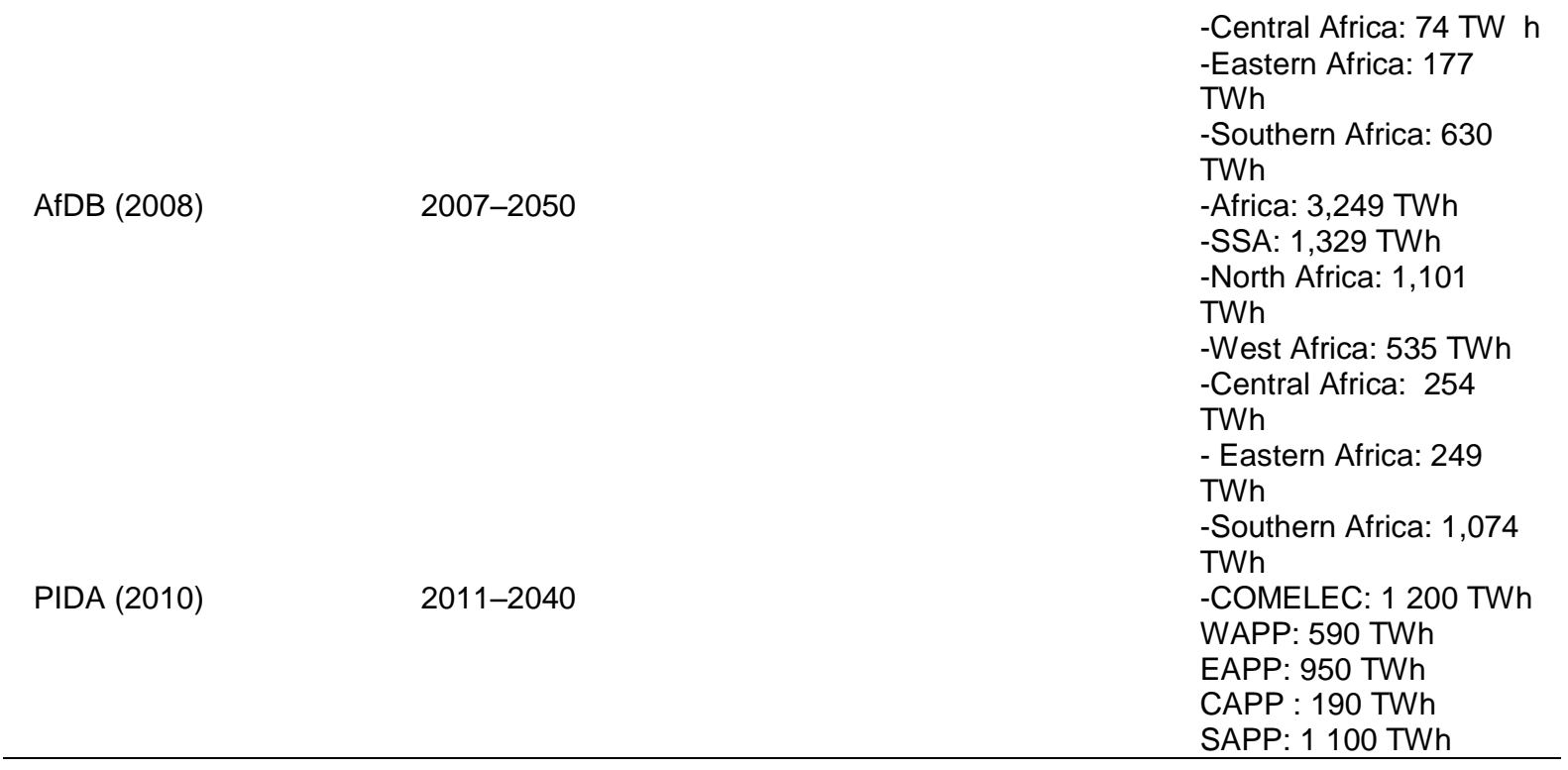

Note: a No detail of the methodology or the software used has been communicated. ${ }^{b} T h e$ Balmorel power system model is an economic and technical partial equilibrium model that simulates the power system and least-cost dispatch. www.bal-morel.comwww.balmorel.com

Source: Author's compilation based on the cited sources, 2016.

Table 3: World rate of electrification

\begin{tabular}{|c|c|c|c|c|c|c|}
\hline & $\begin{array}{l}\text { Population } \\
\text { (million) }\end{array}$ & $\begin{array}{l}\text { Population with } \\
\text { electricity } \\
\text { (million) }\end{array}$ & $\begin{array}{l}\text { Population without } \\
\text { electricity } \\
\text { (million) }\end{array}$ & $\begin{array}{l}\text { Electrification } \\
\text { rate }(\%)\end{array}$ & $\begin{array}{l}\text { Urban } \\
\text { electrification } \\
\text { rate }(\%)\end{array}$ & $\begin{array}{l}\text { Rural } \\
\text { electrification } \\
\text { rate (\%) }\end{array}$ \\
\hline Africa & 891 & 337 & 554 & 37.8 & 67.9 & 19.0 \\
\hline Developing Asia & 3,418 & 2,488 & 930 & 72.8 & 86.4 & 85.1 \\
\hline Latin America & 449 & 404 & 45 & 90.0 & 98.0 & 65.6 \\
\hline Middle East & 186 & 145 & 41 & 78.1 & 86.7 & 61.8 \\
\hline $\begin{array}{l}\text { Developing } \\
\text { countries }\end{array}$ & 4,943 & 3,374 & 1,569 & 68.3 & 85.2 & 56.4 \\
\hline $\begin{array}{l}\text { Transition } \\
\text { economies \& } \\
\text { OECD }\end{array}$ & 1,501 & 1,501 & 8 & 99.5 & 100.0 & 98.1 \\
\hline World & 6,452 & 4,875 & 1,577 & 75.6 & 90.4 & 61.7 \\
\hline
\end{tabular}

Source: Author's compilation based on Enerdata (2015) and World Bank (2015). 
Table 4: Installed capacity by power pool, 2014

\begin{tabular}{llllll}
\hline & CAPP 2014 & COMELEC 2014 & EAPP 2014 & SAPP 2014 & WAPP 2014 \\
\hline Installed capacity (MW) & 6,073 & 27,347 & 28,374 & 49,877 & 14,091 \\
Hydropower share (\%) & $86 \%$ & $8 \%$ & $24 \%$ & $17 \%$ & $30 \%$ \\
Thermal share (\%) & $14 \%$ & $91 \%$ & $73 \%$ & $83 \%$ & $70 \%$ \\
Populations (millions) & 150 & 92.1 & 452 & 207 & 330.2 \\
KW/1,000 habitants & 51 & 421 & 124 & 319 & 70 \\
\hline
\end{tabular}

Source: Author's compilation based on Enerdata (2015) and World Bank (2015).

Table 5: Regional electricity demand (terawatt-hours)

\begin{tabular}{lllllll}
\hline Regions & 2015 & 2020 & 2025 & 2030 & 2035 & 2040 \\
\hline WAPP & 70.2 & 88.7 & 112.8 & 144.6 & 186.9 & 243.5 \\
EAPP & 207.9 & 263.5 & 338.7 & 440.9 & 580.9 & 774.1 \\
SAPP & 285.6 & 364.6 & 469.4 & 609.9 & 800.1 & 1060.6 \\
CAPP & 19.4 & 25.3 & 34.0 & 46.9 & 66.1 & 94.5 \\
Total & 583.1 & 742.0 & 954.8 & $1,242.3$ & $1,634.0$ & $2,172.8$ \\
\hline
\end{tabular}

Source: LEAP simulation results, 2016 
Table 6: GHG emission by scenarios, in million metric tonnes

\begin{tabular}{|c|c|c|c|c|c|c|}
\hline \multirow[b]{2}{*}{ Regions } & \multicolumn{3}{|l|}{2015} & \multicolumn{3}{|l|}{2040} \\
\hline & $\begin{array}{l}\text { Carbon } \\
\text { dioxide }\end{array}$ & $\begin{array}{l}\text { Carbon dioxide } \\
\text { biogenic }\end{array}$ & $\begin{array}{l}\text { Total } \\
\text { emissions }\end{array}$ & $\begin{array}{l}\text { Carbon } \\
\text { dioxide }\end{array}$ & $\begin{array}{l}\text { Carbon dioxide } \\
\text { biogenic }\end{array}$ & $\begin{array}{l}\text { Total } \\
\text { emissions }\end{array}$ \\
\hline \multicolumn{7}{|c|}{ Reference scenario } \\
\hline WAPP & 28.4 & 4.24 & 32.8 & 48.2 & 13.2 & 61.9 \\
\hline EAPP & 70.7 & 0.85 & 71.8 & 153.2 & 6.3 & 160.7 \\
\hline SAPP & 307.1 & 1.15 & 312.4 & 486.3 & 1.3 & 494.3 \\
\hline CAPP & 1.7 & .. . & 1.70 & 3.7 & - & 3.8 \\
\hline Total region & 407.8 & 6.23 & 418.7 & 691.5 & 20.8 & 720.7 \\
\hline \multicolumn{7}{|c|}{ Renewable energy scenario } \\
\hline WAPP & 25.2 & 4.8 & 30.1 & 37.5 & 23.0 & 60.9 \\
\hline EAPP & 72.6 & 1.0 & 73.9 & 119.5 & 3.5 & 123.7 \\
\hline SAPP & 292.6 & 2.4 & 299.0 & 477.8 & 3.7 & 488.1 \\
\hline CAPP & 1.7 & 0.0 & 1.7 & 3.7 & 0.7 & 4.5 \\
\hline Total region & 392.1 & 8.2 & 404.7 & 638.5 & 30.9 & 677.2 \\
\hline \multicolumn{7}{|c|}{ Energy efficiency Demand-side scenario } \\
\hline WAPP & 23.2 & 3.7 & 27.1 & 36.6 & 6.0 & 42.9 \\
\hline EAPP & 69.5 & 0.8 & 70.6 & 127.0 & 3.9 & 131.8 \\
\hline SAPP & 309.2 & 1.1 & 314.5 & 471.7 & 1.1 & 479.2 \\
\hline CAPP & 1.9 & 0.0 & 1.9 & 2.3 & 0.0 & 2.3 \\
\hline Total region & 403.8 & 5.6 & 414.0 & 637.5 & 11.0 & 656.2 \\
\hline \multicolumn{7}{|c|}{ Efficiency supply-side scenario } \\
\hline WAPP & 23.4 & 3.9 & 27.5 & 38.4 & 9.9 & 48.7 \\
\hline EAPP & 65.3 & 0.8 & 66.3 & 119.0 & 5.5 & 125.5 \\
\hline SAPP & 284.7 & 1.1 & 289.7 & 390.5 & 1.2 & 397.0 \\
\hline CAPP & 1.5 & 0.0 & 1.5 & 2.4 & 0.0 & 2.5 \\
\hline Total region & 374.8 & 5.8 & 385.0 & 550.3 & 16.6 & 573.6 \\
\hline
\end{tabular}

Note: ${ }^{\text {aThe }}$ others GHGs emissions including sulphur dioxide, nitrous oxide, nitrogen oxides, methane, carbon monoxide, etc. are relatively low. Source: LEAP simulation results, 2016. 
Figure 1: Electricity demand

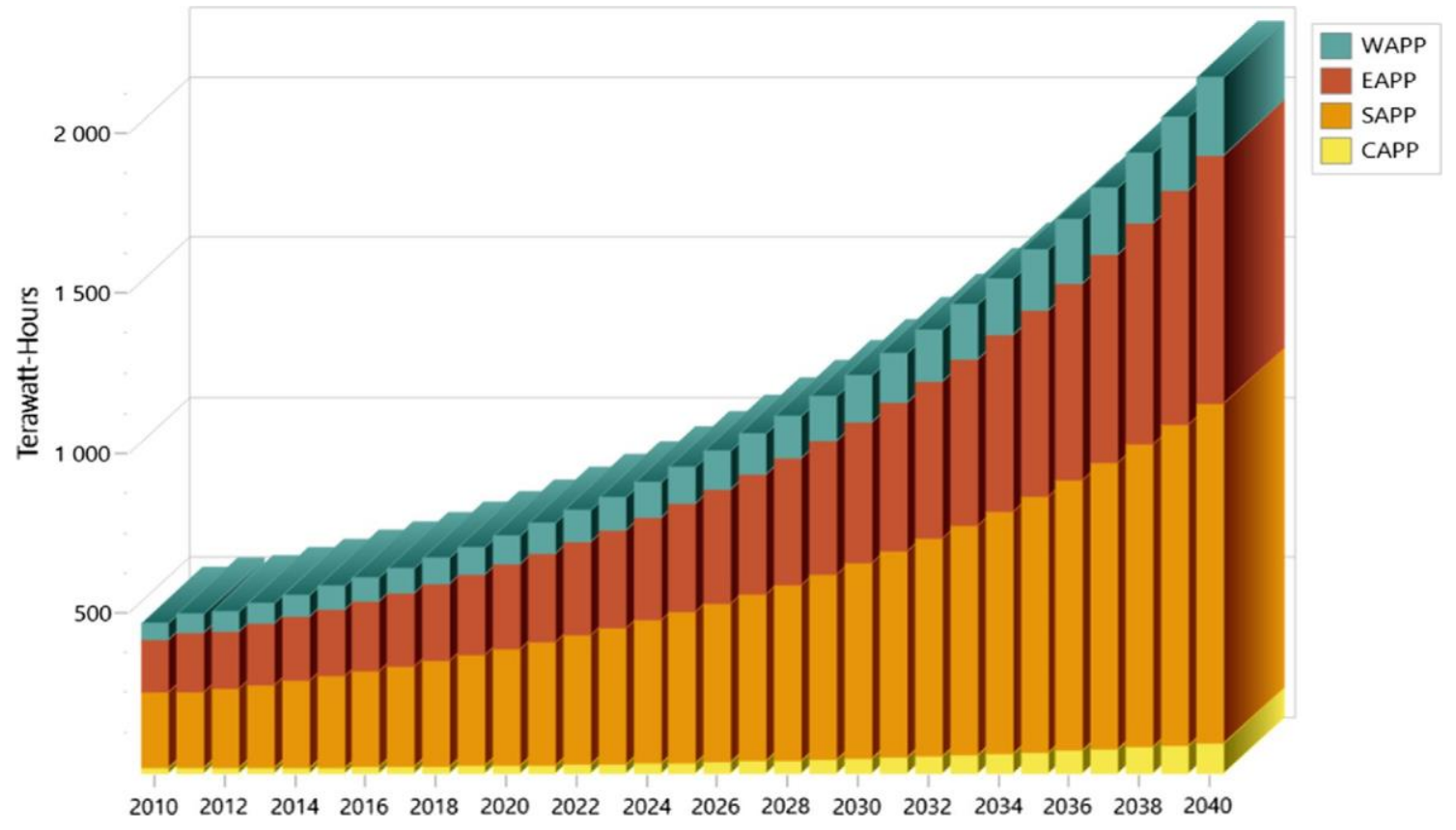

Source: LEAP simulation results, 2016.

Figure 2: Electricity demand, WAPP

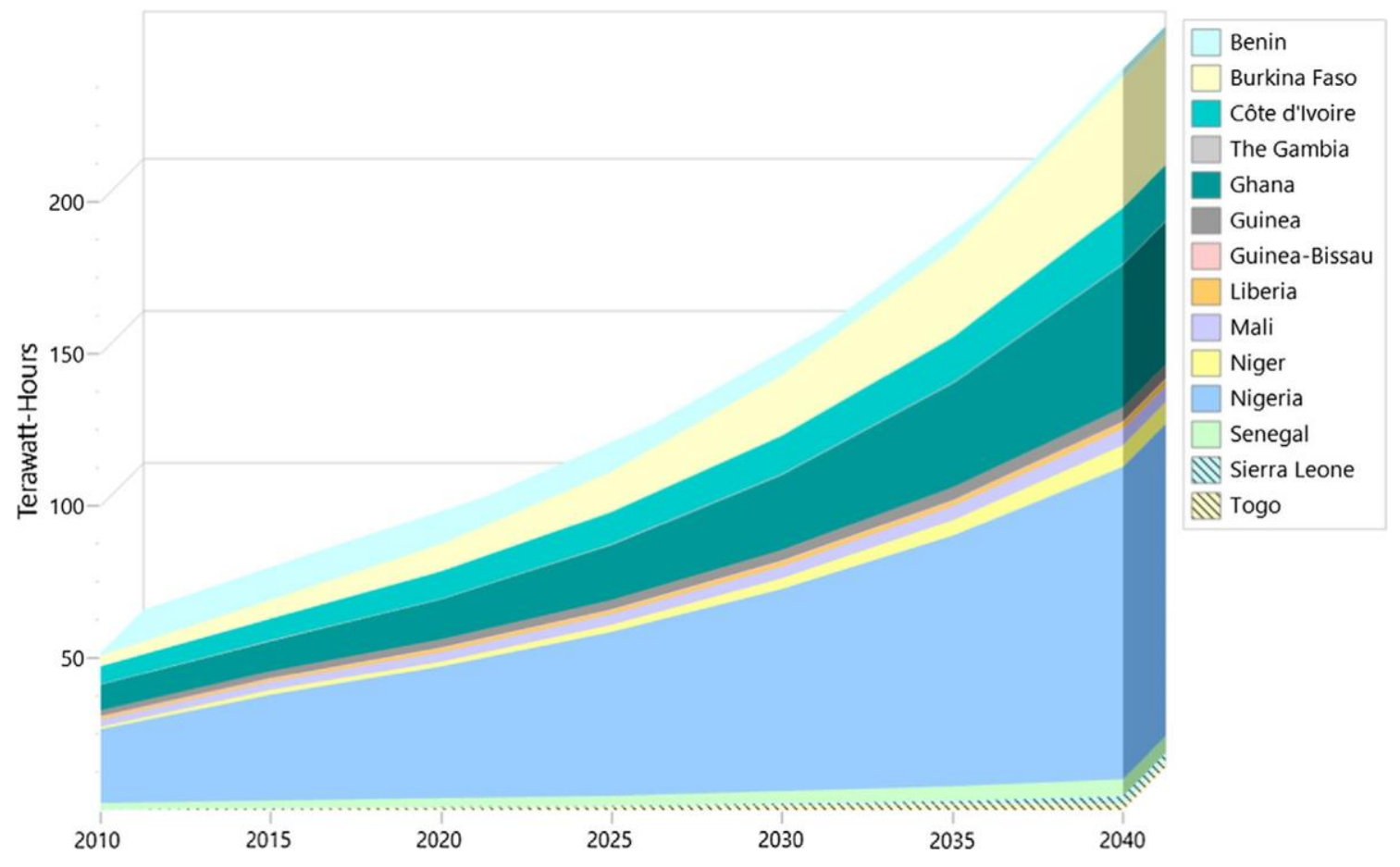

Source: LEAP simulation results, 2016. 
Figure 3: Total electricity demand, CAPP

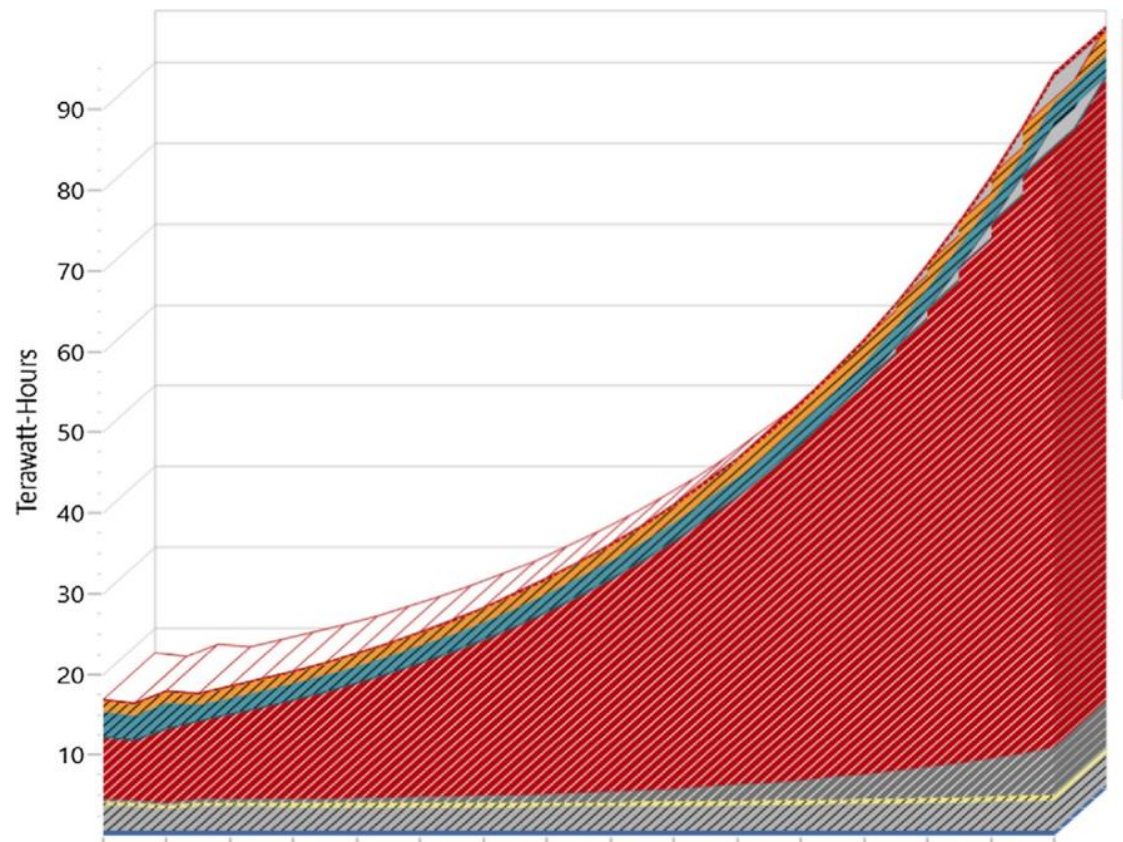

$\mathbb{N}$ Burundi2

V/A Angola

$\mathbb{V}$ Cameroon

U/A Central African Republic

Whad

Th Democratic Republic of the Congo

Ua Republic of Congo

Equatorial Guinea

V//, Gabon

E São Tomé and Príncipe

$201020122014201620182020202220242026 \quad 202820302032 \quad 2034 \quad 2036 \quad 20382040$

Source: LEAP simulation results, 2016.

Figure 4: Total electricity demand, EAPP

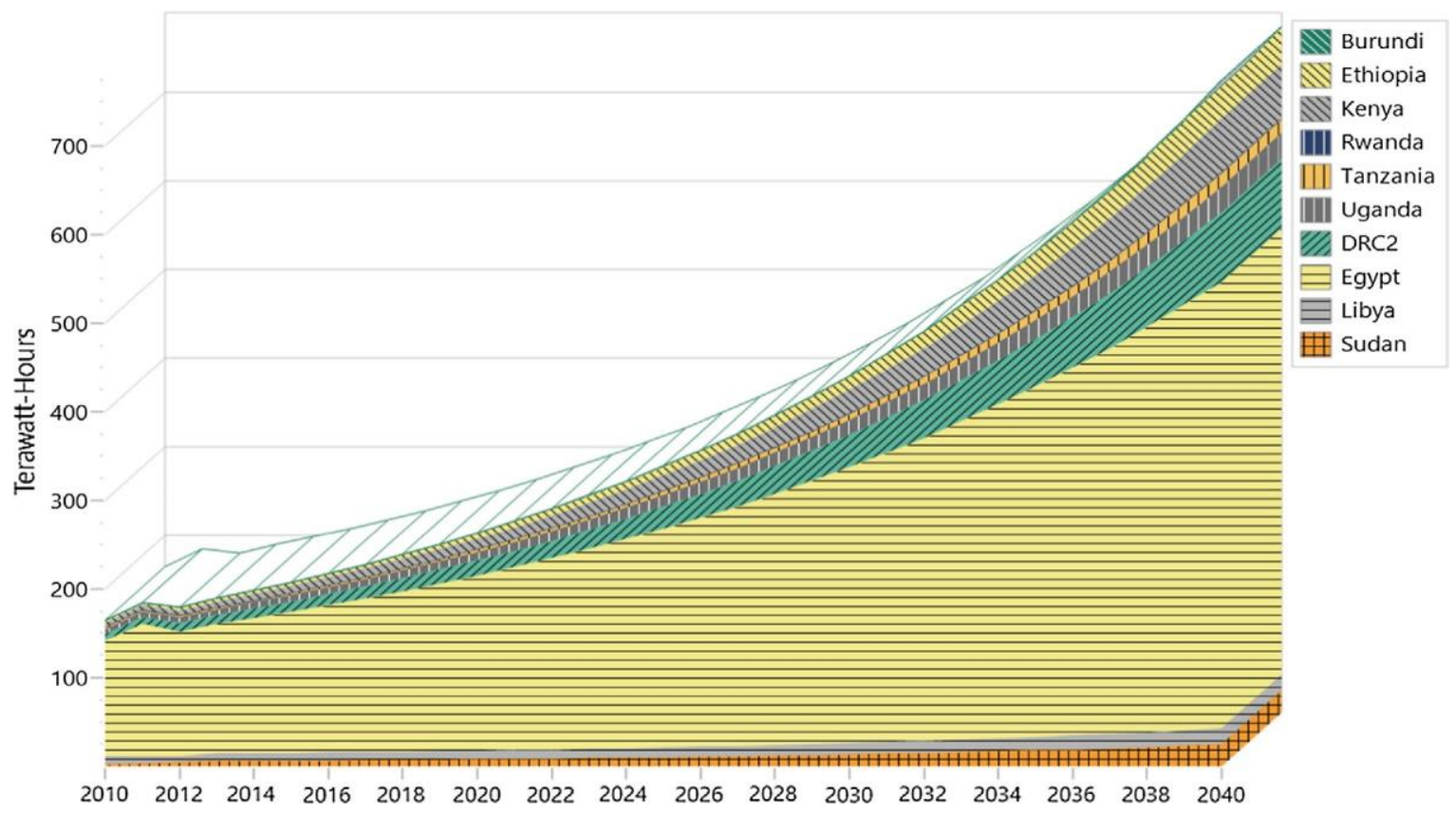

Source: LEAP simulation results, 2016. 
Figure 5: Total electricity demand, SAPP

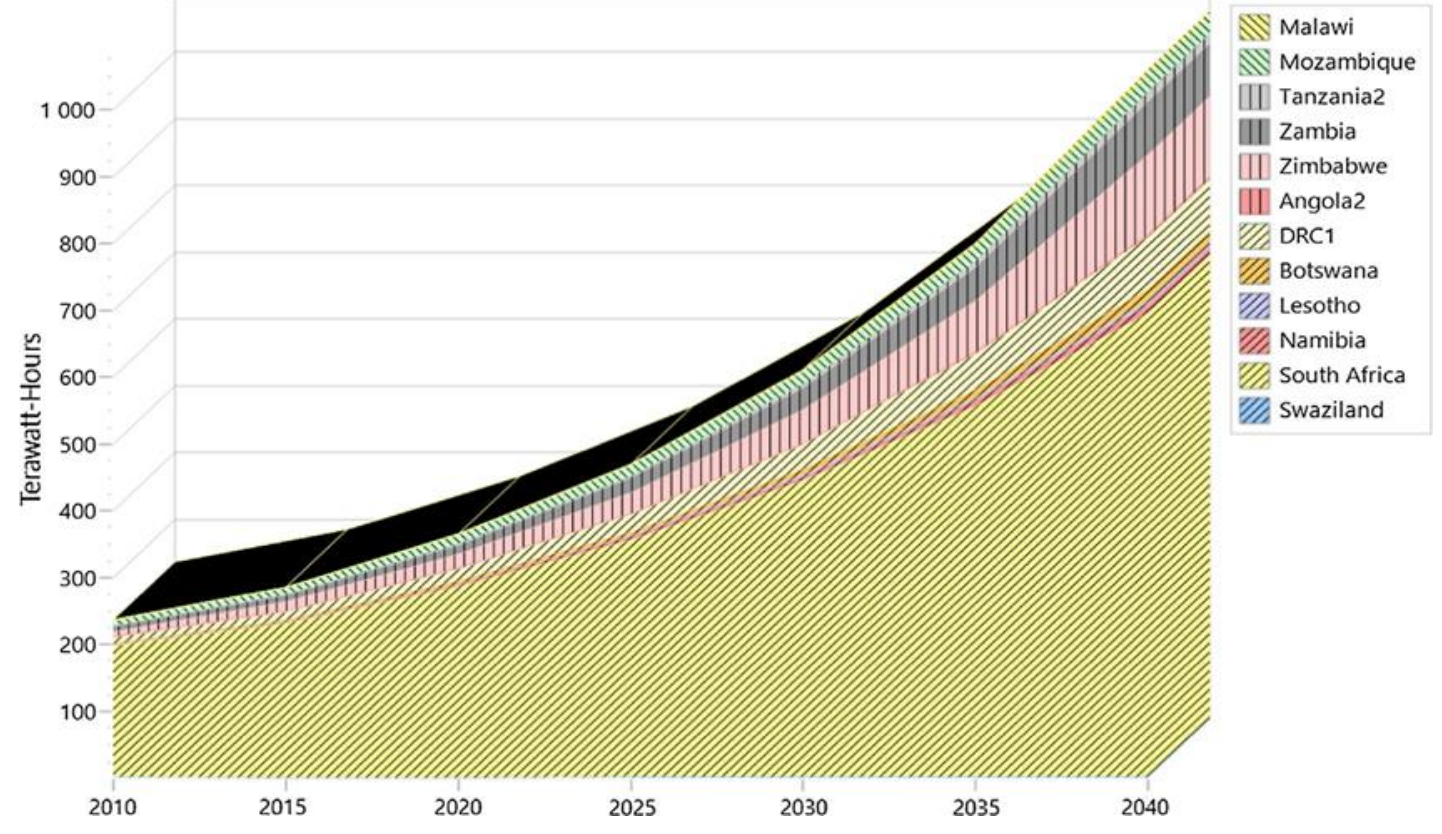

Source: LEAP simulation results, 2016.

Figure 6: Generated electricity by type of power plant in 2015

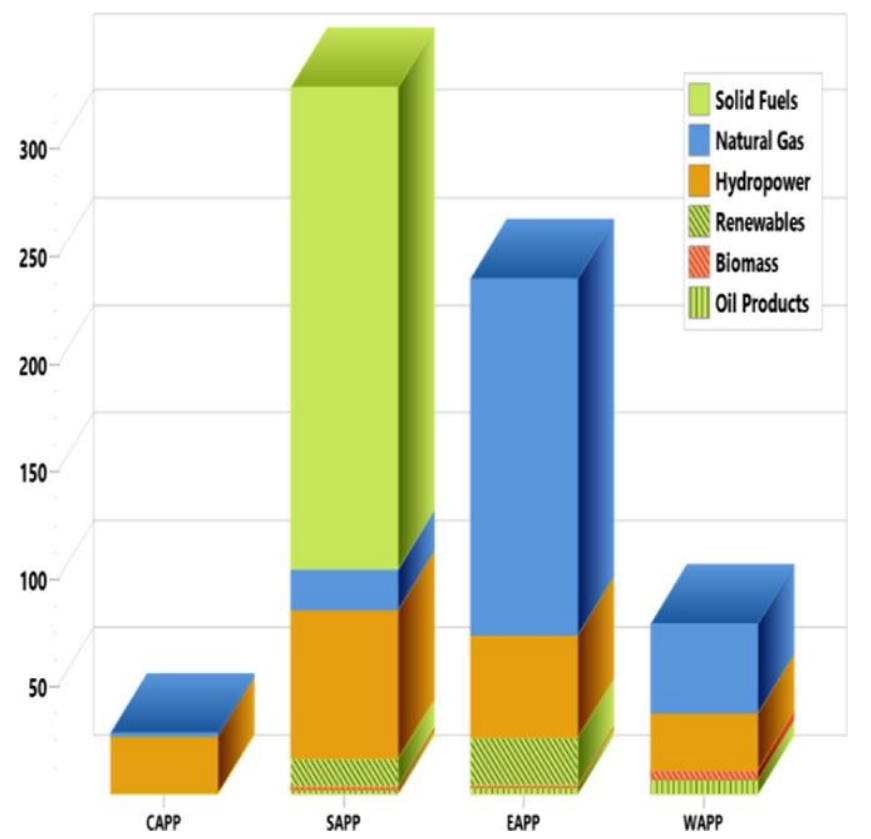

Source: 
Figure 7: Generated electricity by type of power plant in 2040 (TW h)

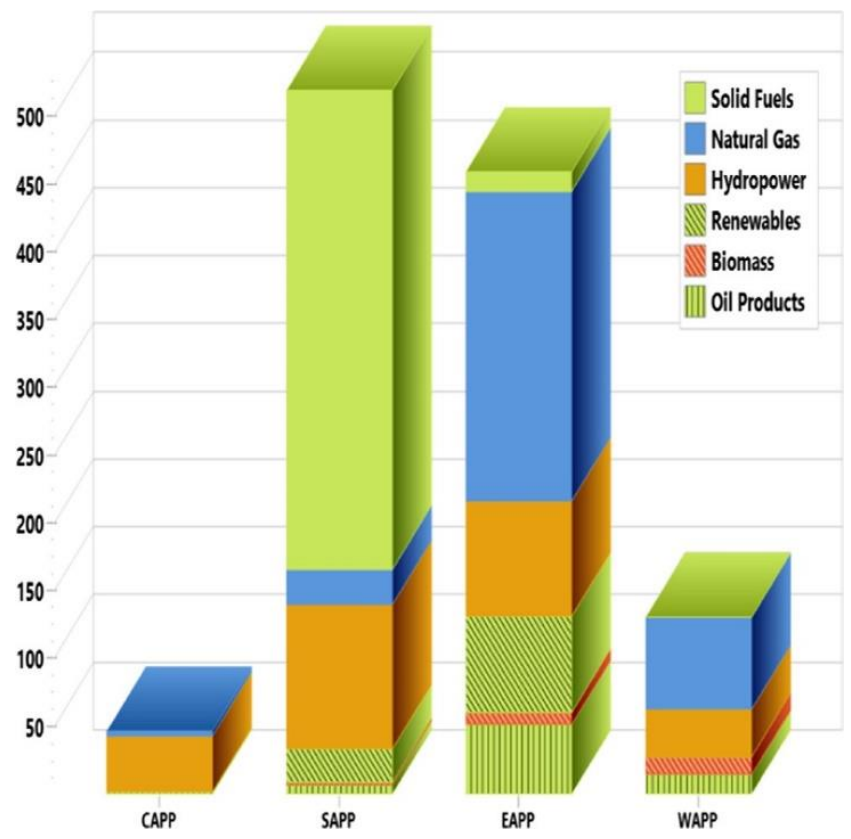

Source: LEAP simulation results, 2016

Figure 8: Generated electricity by type of power plant under the renewables scenario in 2040 (\%)

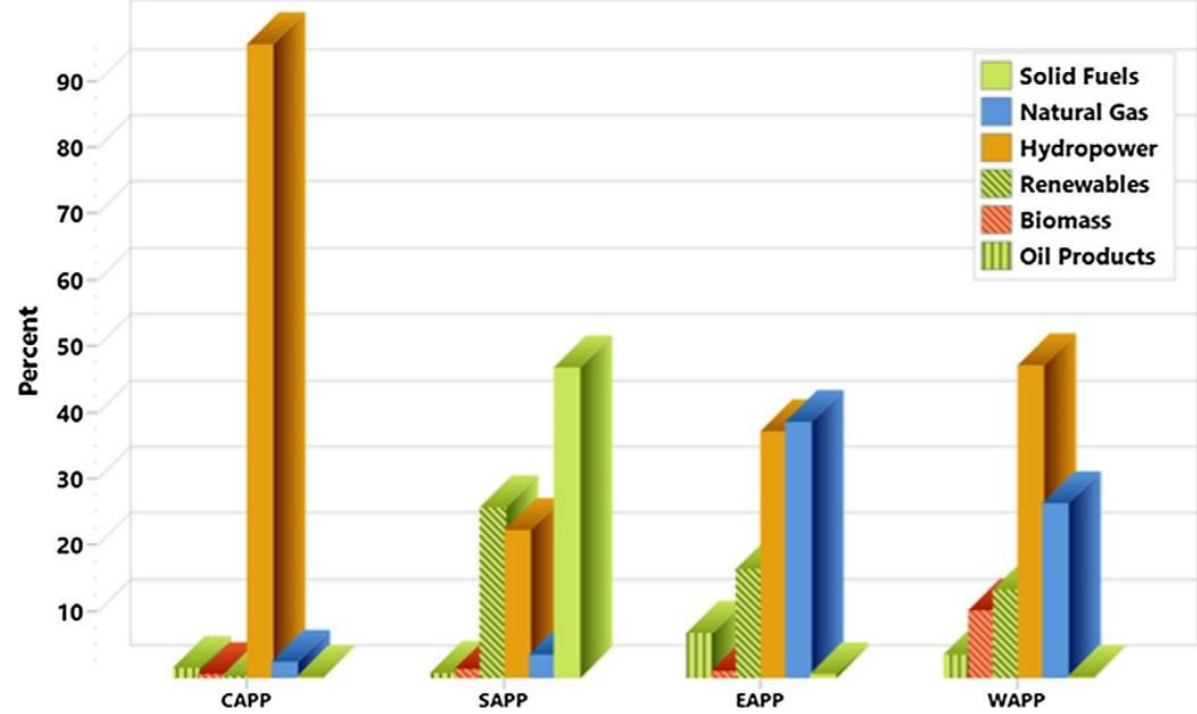

Source: LEAP simulation results, 2016. 
Figure 9: Savings in electricity generation under the efficiency supply-side scenario, 2040

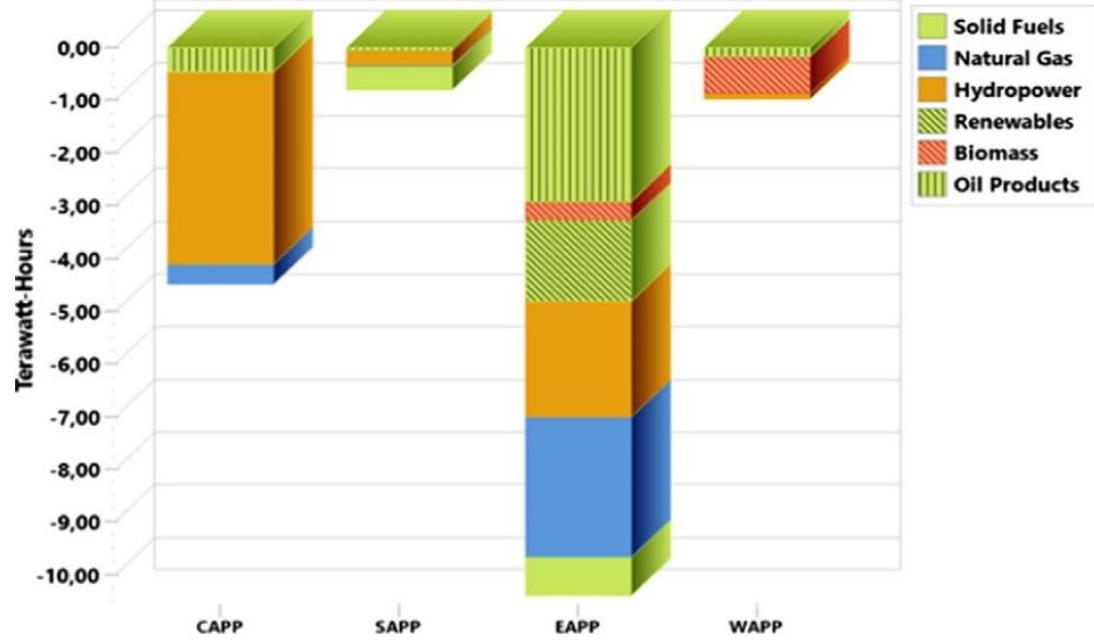

Source: LEAP simulation results, 2016.

Figure 10: Savings in electricity generation under the efficiency demand-side scenario, 2040

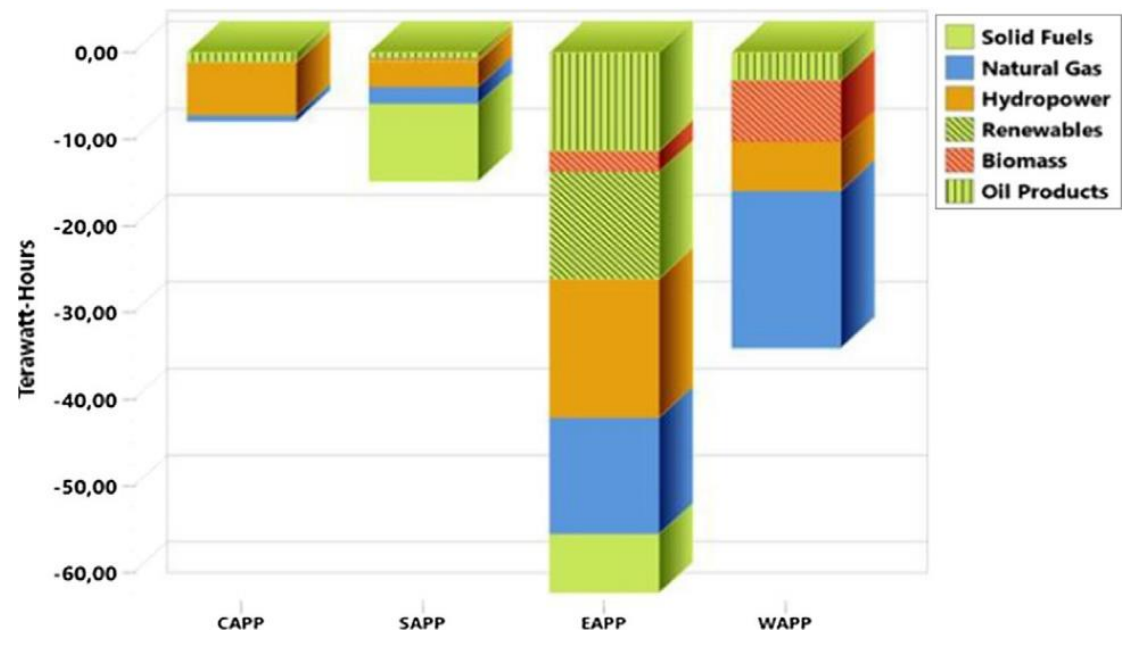

Source: LEAP simulation results, 2016. 


\section{Appendix}

Figure A1: Map of African electricity grid, showing the various existing and proposed power pool projects

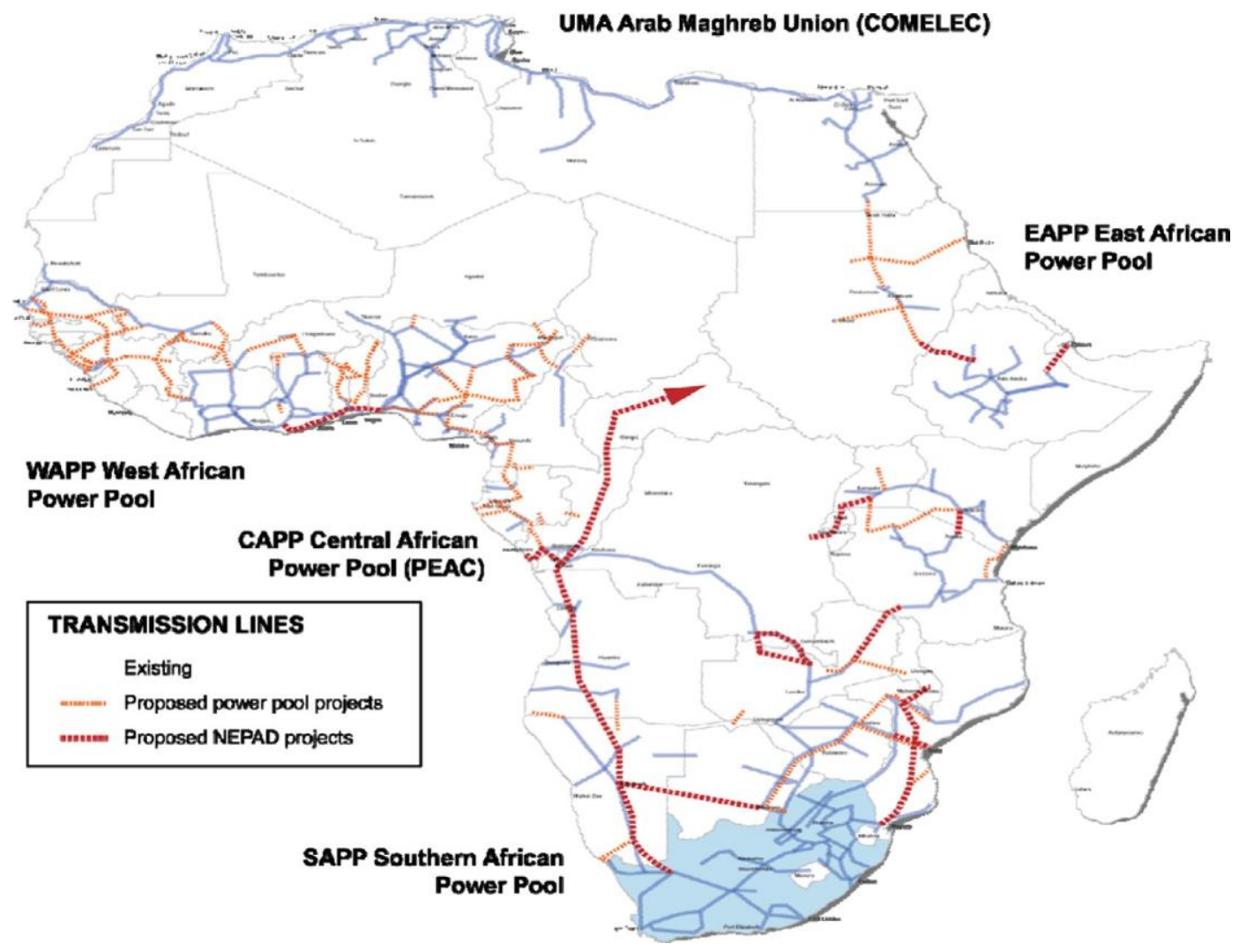

Source: Global Energy Network Institute, (n.d.).

Figure A2: Projected sectoral electricity demand in 2040 (terawatt-hours)

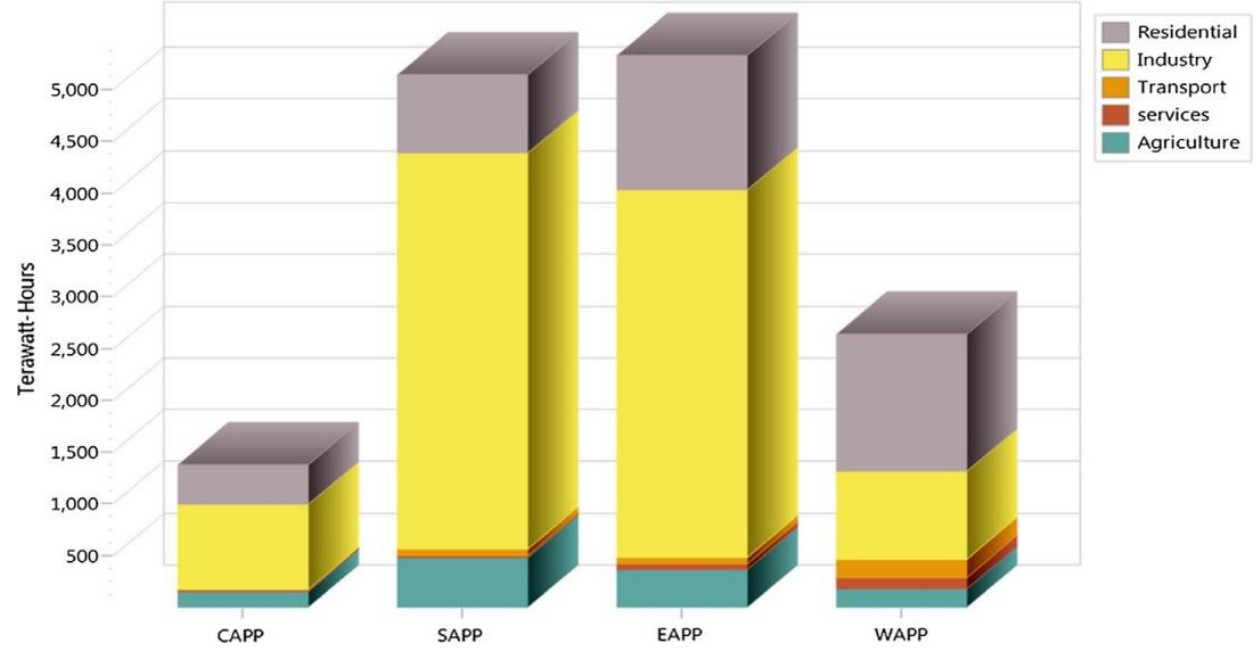

Source: LEAP simulation results, 2016. 
Figure A3: System energy load

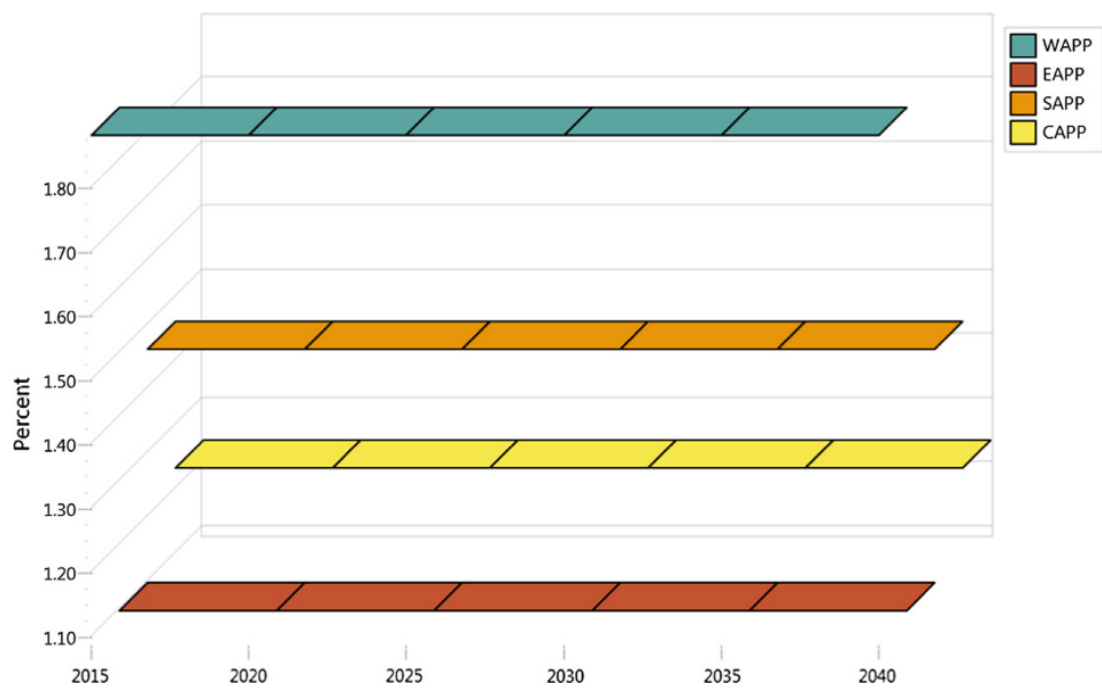

Shape

Source: LEAP simulation results, 2016.

Figure A4: Peak power requirements

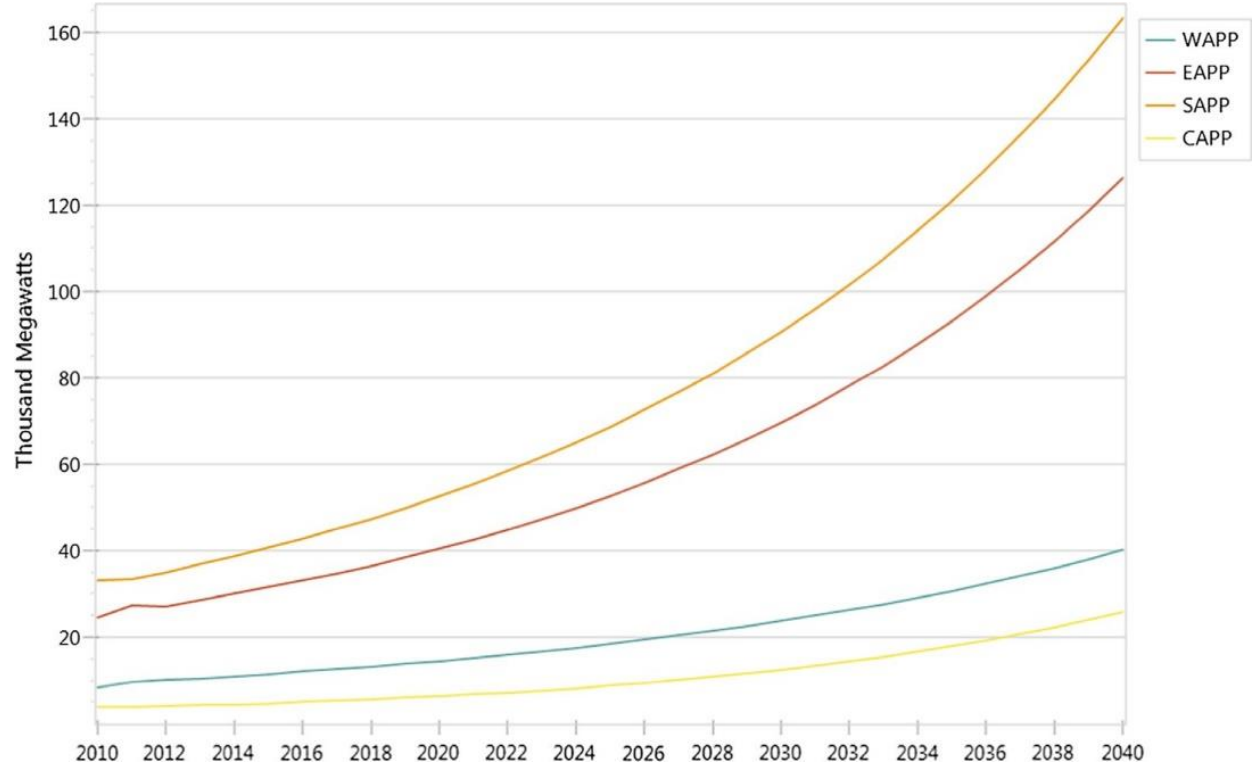

Source: LEAP simulation results, 2016. 
Figure A5: System energy load shape (percentage of annual energy load), Cameroon

Source: LEAP simulation results, 2016.

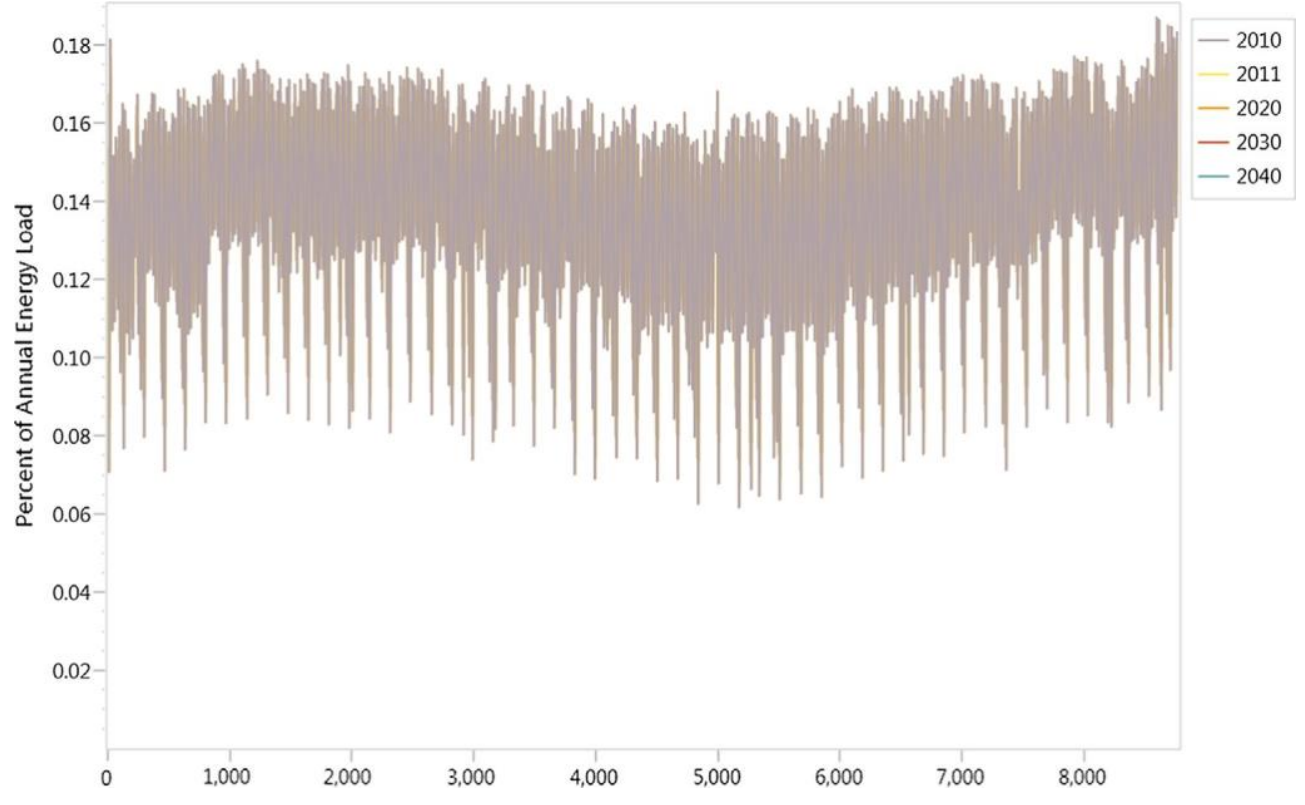

Figure A6: System energy load shape (percentage of annual energy load), Ghana

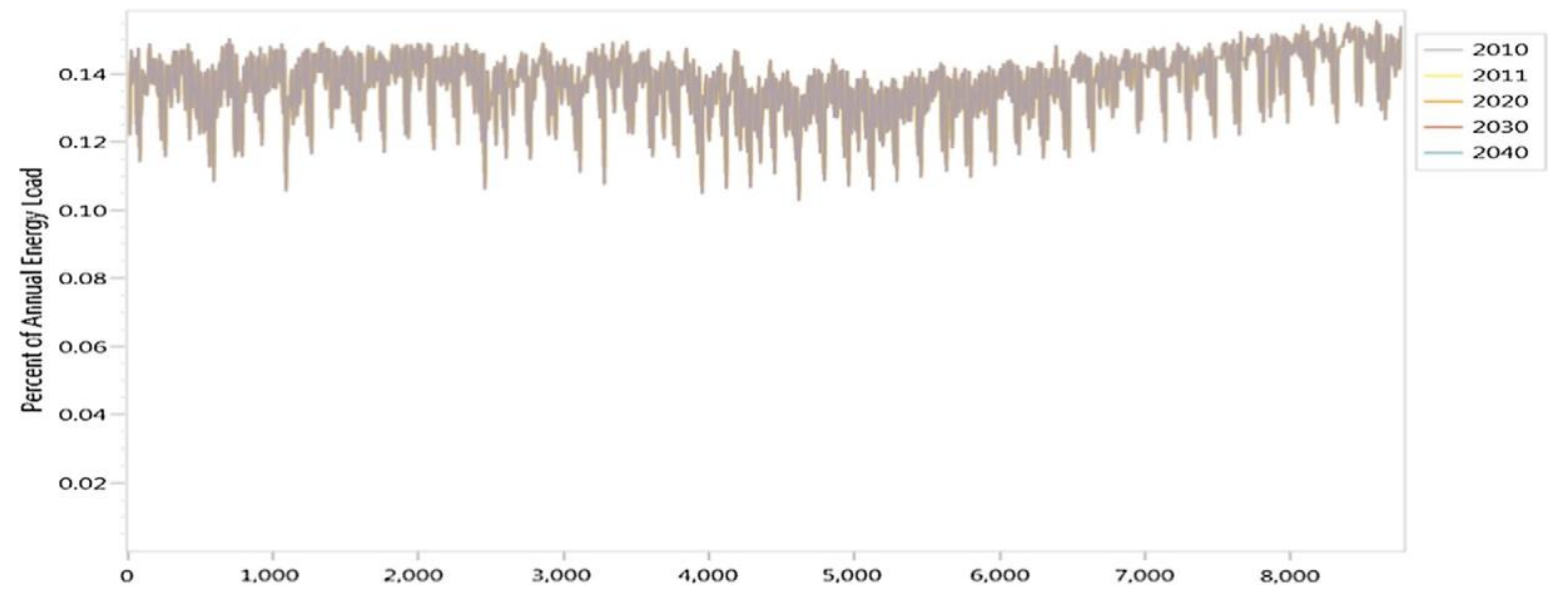

Source: LEAP simulation results, 2016. 
Figure A7: System energy load shape (percentage of annual energy load), DRC

Source: LEAP simulation results, 2016.

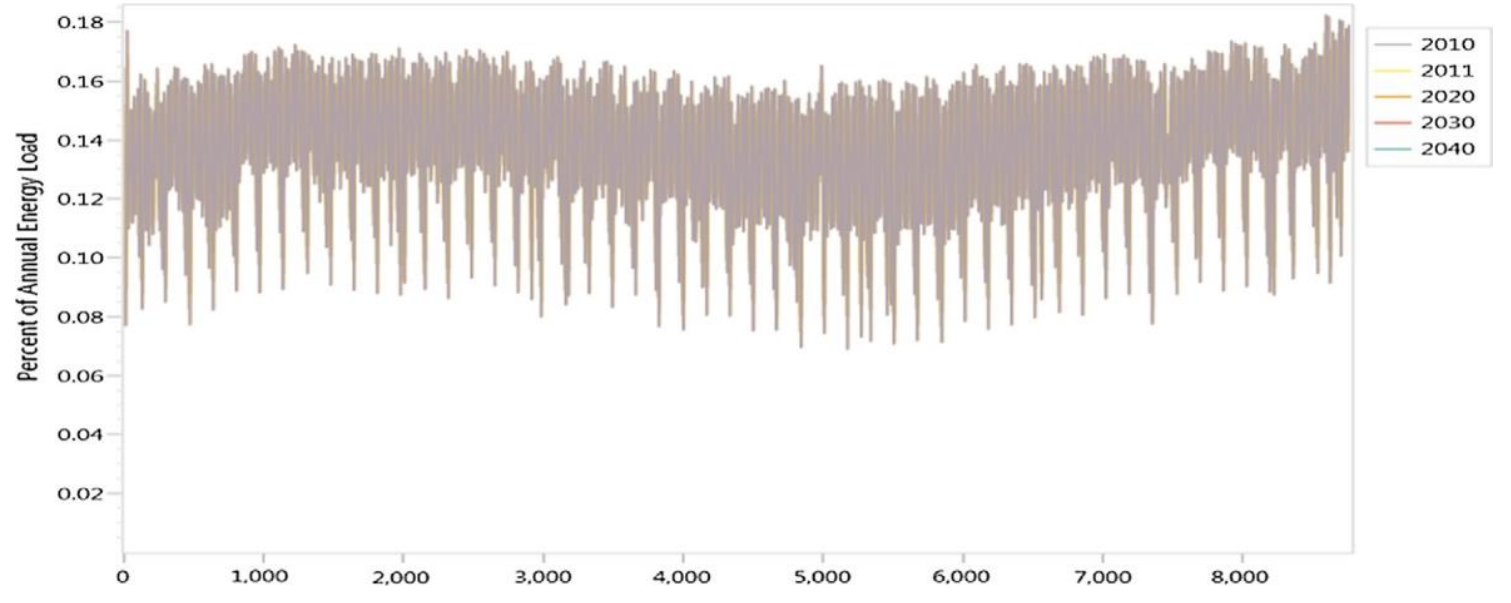

Figure A8: System energy load shape (percentage of annual energy load), Mozambique

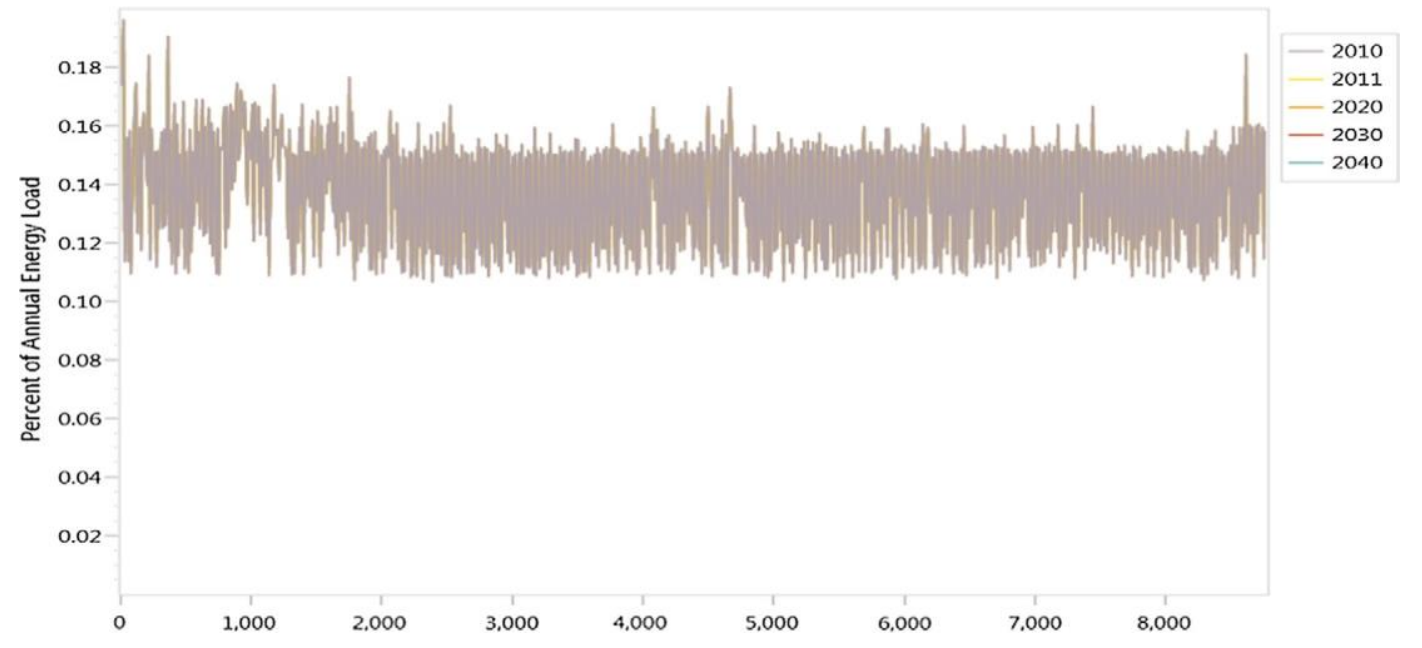

Source: LEAP simulation results, 2016 
Table A1

Classification of energy systems models and their options - purpose and structure

\begin{tabular}{|c|c|}
\hline Model & $\begin{array}{l}\text { Name of model and } \\
\text { developer }\end{array}$ \\
\hline Purpose of the model & $\begin{array}{l}\text { General Forecasting } \\
\text { Exploring } \\
\text { Backcasting } \\
\text { Specific } \\
\text { Energy } \\
\text { demand } \\
\text { Energy supply } \\
\text { Impacts } \\
\text { Environmenta } \\
\text { Appraisal } \\
\text { Integrated } \\
\text { approach } \\
\text { Modular } \\
\text { Build-up }\end{array}$ \\
\hline $\begin{array}{l}\text { Structure of the model: internal assumptions \& } \\
\text { external assumptions }\end{array}$ & $\begin{array}{l}\text { Degree of } \\
\text { endogenization } \\
\text { Description of non- } \\
\text { energy sectors } \\
\text { Description of end-use } \\
\text { Description of supply }\end{array}$ \\
\hline & $\begin{array}{l}\text { technologies } \\
\text { Supply or Demand } \\
\text { analysis tool }\end{array}$ \\
\hline Geographical coverage Global & $\begin{array}{l}\text { Regional } \\
\text { National } \\
\text { Local/community } \\
\text { Single-project }\end{array}$ \\
\hline Sectoral coverage & $\begin{array}{l}\text { Energy sectors } \\
\text { Other specific sectors } \\
\text { Overall economy }\end{array}$ \\
\hline The time horizon Short & $\begin{array}{l}\text { Medium } \\
\text { Long Term }\end{array}$ \\
\hline The time step Minutely & $\begin{array}{l}\text { Hourly } \\
\text { Monthly } \\
\text { Yearly } \\
\text { Five-yearly } \\
\text { User-defined }\end{array}$ \\
\hline
\end{tabular}

Source: Based on Hall and Buckley (2016).
Table A2

Classification of energy systems models - mathematical description

\begin{tabular}{|c|c|}
\hline Model & Name of the model \\
\hline The Analytical Approach Top-Down & $\begin{array}{l}\text { Bottom-Up } \\
\text { Hybrid } \\
\text { Other }\end{array}$ \\
\hline The Underlying Methodology Econometric & $\begin{array}{l}\text { Macro-Economic } \\
\text { Micro-Economic } \\
\text { Economic Equilibrium } \\
\text { Optimization } \\
\text { Simulation } \\
\text { Stochastic/Monte-Carlo } \\
\text { Spatial (GIS) } \\
\text { Spreadsheet/Toolbox } \\
\text { Backcasting } \\
\text { Multi-Criteria } \\
\text { Accounting }\end{array}$ \\
\hline $\begin{array}{l}\text { The Mathematical Approach Linear } \\
\text { programming }\end{array}$ & $\begin{array}{l}\text { Mixed-integer } \\
\text { programming } \\
\text { Dynamic programming } \\
\text { Fuzzy logic } \\
\text { Agent based programming }\end{array}$ \\
\hline Data Requirements Qualitative & $\begin{array}{l}\text { Quantitative } \\
\text { Monetary } \\
\text { Aggregated } \\
\text { Disaggregated }\end{array}$ \\
\hline
\end{tabular}

Source: Based on Hall and Buckley (2016). 
Table A3: Comparative summary of the four scenarios

\begin{tabular}{|c|c|c|c|c|c|}
\hline & & Reference & Renewables & Demand efficiency & Supply side \\
\hline Electricty demand (TWh) & WAP & 243.52 & 243.52 & 117.09 & 243.52 \\
\hline \multirow[t]{2}{*}{ Power generation (TWh) } & WAP & 130.40 & 219.93 & 96.40 & 129.42 \\
\hline & $\begin{array}{l}\text { EAPP } \\
\text { SAPP } \\
\text { CAPP } \\
\text { Total }\end{array}$ & $\begin{array}{l}459.51 \\
519.18 \\
46.24 \\
1155.33\end{array}$ & $\begin{array}{l}568.93 \\
742.42 \\
133.42 \\
1664.71\end{array}$ & $\begin{array}{l}397.23 \\
504.34 \\
38.36 \\
1036.33\end{array}$ & $\begin{array}{l}449.11 \\
518.37 \\
41.76 \\
1138.66\end{array}$ \\
\hline \multirow[t]{2}{*}{ Energy savings (TWh) } & WAP & - & - & 7.9 & 4.5 \\
\hline & $\begin{array}{l}\text { EAPP } \\
\text { SAPP } \\
\text { CAPP } \\
\text { Total }\end{array}$ & $\begin{array}{l}- \\
-\end{array}$ & $\begin{array}{l}- \\
-\end{array}$ & $\begin{array}{l}14.8 \\
62.3 \\
34.0 \\
119.0\end{array}$ & $\begin{array}{l}0.8 \\
10.4 \\
1.0 \\
16.7\end{array}$ \\
\hline GHGs million metric & WAP & 61.90 & 60.90 & 42.90 & 48.70 \\
\hline
\end{tabular}

Source: LEAP simulation results, 2016. 